\title{
Historical and future quantification of terrestrial carbon sequestration from a Greenhouse-Gas-Value perspective
}

\author{
Anita D. Bayer*, Thomas A.M. Pugh, Andreas Krause, Almut Arneth \\ Karlsruhe Institute of Technology, Institute of Meteorology and Climate Research - Atmospheric Environmental Research (IMK-IFU), Kreuzeckbahnstr. 19, \\ 82467 Garmisch-Partenkirchen, Germany
}

\section{Keywords:}

Carbon sequestration

Climate regulation

Greenhouse Gas Value

LPJ-GUESS

Land-use change

Ecosystem services

\begin{abstract}
A B S T R A C T
Terrestrial ecosystems provide a range of important services to humans, including global and regional climate regulation. These services arise from natural ecosystem functioning as governed by drivers such as climate, atmospheric carbon dioxide mixing ratio, and land use change. From the perspective of carbon sequestration, numerous studies have assessed trends and projections of the past and future terrestrial carbon cycle, but links to the ecosystem service concept have been hindered by the lack of appropriate quantitative service metrics. The recently introduced concept of the Greenhouse Gas Value (GHGV) accounts for the land atmosphere exchanges of multiple greenhouse gases by taking into consideration the associated ecosystem pool sizes, annual exchange fluxes and probable effects of natural disturbance in a time sensitive manner.

We use here GHGV as an indicator for the carbon sequestration aspects of the climate regulation ecosystem service, and quantify it at global scale using the LPJ GUESS dynamic global vegetation model. The response of ecosystem dynamics and ecosystem state variables to trends in climate, atmospheric carbon dioxide levels and land use simulated by LPJ GUESS are used to calculate the contribution of carbon dioxide to GHGV. We evaluate global variations in GHGV over historical periods and for future scenarios (1850 2100) on a biome basis following a high and a low emission scenario.

GHGV is found to vary substantially depending on the biogeochemical processes represented in LP GUESS (e.g. carbon nitrogen coupling, representation of land use). The consideration of disturbance events that occur as part of an ecosystem's natural dynamics is crucial for realistic GHGV assessments; their omission results in unrealistically high GHGV. By considering the biome specific response to current climate and land use, and their projections for the future, we highlight the importance of all forest biomes for maintaining and increasing biogeochemical carbon sequestration. Under future climate and carbon dioxide levels following a high emission scenario GHGV values are projected to increase, especially so in tropical forests, but land use change (e.g. deforestation) opposes this trend. The GHGV of ecosystems, especially when assessed over large areas, is an appropriate metric to assess the contribution of different greenhouse gases to climate and forms a basis for the monetary valuation of the climate regulation service ecosystems provide.
\end{abstract}

\section{Introduction}

The provision of terrestrial ecosystem services (ES, MEA, 2005; Haines Yong and Potschin, 2013, for recent classification of ES) is variable in time and space, in response to changes in the environment such as climate warming and land use/land cover changes (LULCC). Expecting that anthropogenic pressures on terrestrial resources will continue to grow over the coming

\footnotetext{
* Corresponding author. Tel.: +49 8821183 121; fax: +49 882173573.

E-mail addresses: anita.bayer@kit.edu (A.D. Bayer), Thomas.pugh@kit.edu (Thomas A.M. Pugh), Andreas.krause@kit.edu (A. Krause), Almut.arneth@kit.edu (A. Arneth)
}

decades, it is becoming increasingly important to understand the regionally disparate behavior of ES and their transition over time. In this context, one globally relevant ecosystem service that is strongly modified by human induced environmental changes is climate regulation, especially the ability of the biosphere to either sequester or emit greenhouse gases (GHG) (MEA, 2005). The exchange of GHGs between the ecosystem and the atmosphere is usually quantified by accounting for changes in the organic matter stored in an ecosystem (e.g. REDD+, see Miles and Kapos, 2008; UNFCCC, 2008), the flux of GHG to or from the atmosphere (e.g. CCX, 2009; Lal, 2004), or a combination of both (e.g. IPCC, 2006; see Anderson Teixeira and DeLucia, 2011, for an extensive summary). However, each of these methods neglects one or more aspects of 
system behavior, and thus fails to account for all of the contributions of ecosystems to regional and global climate.

The Greenhouse Gas Value (GHGV) of ecosystems, a compre hensive method to quantify the contribution of terrestrial ecosystems to biogeochemical aspects of climate regulation was recently introduced by Anderson Teixeira and DeLucia (2011, abbreviated AT\&D11 henceforth). GHGV assesses the value of maintaining an ecosystem over a multi year time frame by calculating the change in GHG induced radiative forcing that would result from the clearing of 1 ha of the ecosystem. The method considers multiple GHGs released through oxidation of stored organic material upon clearing of the ecosystem, as well as the displaced annual GHG flux, including the probable effects of large natural disturbances in the ecosystem. The GHGV of an ecosystem thus is not only determined by high organic matter storage that would be released upon clearance, the value is enhanced if that ecosystem would have continued to take up carbon if it had not been cleared, and if at the same time the probability of being severely affected by natural disturbances (e.g. fire, insect attack, wind throw) over the assessment period is low. The contributions from storage, annual flux, and the effects of disturbance, are expressed relative to the radiative forcing of a pulse $\mathrm{CO}_{2}$ emission, with $\mathrm{GHGV}$ being expressed in $\mathrm{Mg} \mathrm{CO}$ equiv. ha ${ }^{-1}$.

An observation based estimation of ecosystem GHGV (e.g. AT\&D11; Anderson Teixeira et al., 2012) is limited by data availability and quality. It is particularly problematic in regions where observations are rare. In addition, estimates of GHGV scaled up from plot studies are likely to miss or under sample the effects of large, infrequent disturbances, thereby overestimating both stored organic material and ongoing uptake of carbon. Here we use a dynamic global vegetation model (DGVM) to enable global scale calculation of GHGV and its evolution over time. With a DGVM, the GHGV is derived as a direct result of simulated ecosystem dynamics including disturbances, and changes in GHGV are intrinsically linked to individual biogeochemical processes and environmental and/or anthropogenic drivers. Applying a DGVM allows consideration of how past or future environmental changes affect GHGVs through their effects on ecosystem function. We concentrate here on the carbon sequestration aspects of GHGV ( GHGV of $\mathrm{CO}_{2}$ ) for ecosystems in their potential natural state without and with accounting for interactions of carbon $(\mathrm{C})$ and nitrogen $(\mathrm{N})$ cycles, and under the consideration of agricultural land use. We assess in particular how GHGV varies spatially and through time in response to changes in climate, atmospheric $\mathrm{CO}_{2}$ mixing ratio and land use. We cover in our analysis variations over historical periods (beginning in 1850) and a range of future scenarios (until 2100) under a high (RCP 8.5) and a low (RCP 2.6) emission scenario.

\section{Methods}

\subsection{LPJ GUESS DGVM}

LPJ GUESS DGVM (Smith et al., 2001, 2014; Sitch et al., 2003) is a process based model that simulates vegetation dynamics and biogeochemical cycles as a function of prevailing climate, soil type and atmospheric $\mathrm{CO}_{2}$ mixing ratio (Fig. 1). Potential natural vegetation is modeled by 11 tree and grass plant functional types (PFT; Table S1), which differ in aspects such as photosynthetic pathway, optimum temperature range for photosynthesis, and phenology. Competition for resources and light among age cohorts of woody plant individuals in natural vegetation is simulated directly through gap dynamics (see, e.g. Bugmann, 2001). Vegetation establishment and mortality are treated stochastically across a number of replicate (here: 10) patches, representative for an area of ca. $1000 \mathrm{~m}^{2}$, that are averaged to form a representative sample of vegetation within a grid cell. The model has been evaluated extensively and has demonstrated skill in capturing large scale vegetation patterns (Hickler et al., 2006, 2012) and dynamics of the terrestrial carbon cycle (Ahlström et al., 2012; Morales et al., 2005; Piao et al., 2013). The carbon flux response was shown to be close to the ensemble mean in a recent intercomparison of nine dynamic global vegetation models (Sitch et al., 2013).

In addition to the base version (PNV), two recent developments of the LPJ GUESS model are used here to include the effects of accounting for additional ecosystem processes and nutrient cycles.

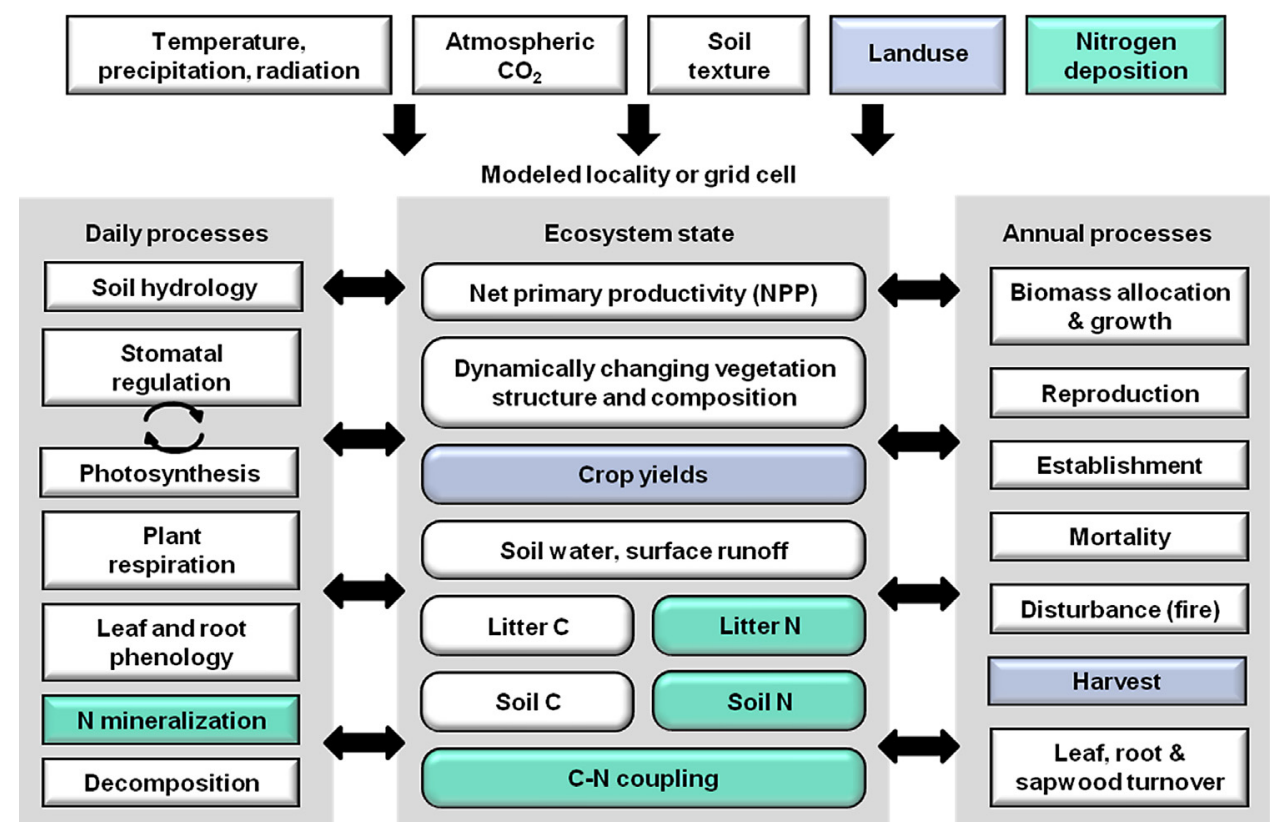

Fig. 1. Major processes within LPJ-GUESS DGVM for the base version simulating potential natural vegetation, and including additional features for considering carbonnitrogen dynamics (highlighted in green, version $\mathrm{PNV}_{\mathrm{N}}$ ) and representing cropland and land-use changes (highlighted in blue, version CLU) (after Smith et al., 2001). (For interpretation of the references to color in this figure legend, the reader is referred to the web version of this article.) 
The first version includes coupled carbon and nitrogen cycling in vegetation and soil for the simulation of potential natural vegetation (see Smith et al., 2014; Wårlind et al., 2014) $\left(\mathrm{PNV}_{\mathrm{N}}\right)$, allowing for the simulation of nitrogen limitation on plant production (e.g. under high atmospheric $\mathrm{CO}_{2}$ ). The second version includes a detailed representation of croplands and land use change (CLU). Pastures used for livestock grazing are modeled using competing C3 and C4 grass PFTs, where each year 50\% of the above ground biomass is removed (see Lindeskog et al., 2013). Agricultural lands are represented by 11 generic crop functional types (CFT) that represent the most widely grown crop species globally (Table S1; Lindeskog et al., 2013; Bondeau et al., 2007). Crop areas are prescribed (see Fig. 1) and CFTs do not compete with each other. Croplands are harvested every year; CFTs may be rainfed or irrigated (Lindeskog et al., 2013). A combined implementation of both $\mathrm{C} \mathrm{N}$ coupling and detailed crop and land use change representation is not yet available.

\subsection{The Greenhouse Gas Value of ecosystems}

The Greenhouse Gas Value (AT\&D11) of ecosystems quantifies the contribution of terrestrial ecosystems to climate by assessing the value of maintaining an ecosystem over a multi year time frame. It does this by calculating the change in radiative forcing due to multiple GHGs that would result from the clearing of 1 ha of the ecosystem. The detailed theoretical development of GHGV and comparison to commonly used metrics for quantifying the GHG contribution of ecosystems is given in AT\&D11. Using the LPJ GUESS model we provide an estimation of the contribution of $\mathrm{CO}_{2}$ to the GHGV of ecosystems (Fig. 2), which represents globally the largest GHG flux between natural ecosystems and the atmosphere (AT\&D11; Schulze et al., 2009). The exchange of other GHGs such as $\mathrm{CH}_{4}$ and $\mathrm{N}_{2} \mathrm{O}$ between the biosphere and the atmosphere is not yet represented within the LPJ GUESS ecosystem model. Following the nomenclature of AT\&D11, we determine in this study
$\operatorname{GHGV}\left(\mathrm{CO}_{2}\right)_{100}{ }^{50}$ ( $\left.\mathrm{Lal}, 2004\right)$ where the sub and superscripts refer to the two time frames over which GHG emission is accounted for (see below) and the term in parenthesis to the determination of the contribution of $\mathrm{CO}_{2}$ only. However, for simplicity we use "GHGV" with a subscript according to the year of removal of natural vegetation in this study.

Ecosystem atmosphere GHG exchange is calculated over an emissions time frame $\left(t_{\mathrm{E}}\right)$, here 50 years following AT\&D11 (see also their discussion of time frames). Because GHGs remain in the atmosphere for many years, the climate impact of the released GHGs is evaluated over a longer analytical time frame $\left(t_{A}\right)$ of 100 years. The chosen length of $t_{\mathrm{E}}$ and $t_{\mathrm{A}}$ takes into consideration the decomposition rates of organic matter, statistical recurrence of disturbance within major ecosystems and consistency with other GHG quantification methods (e.g. IPCC, 2007a).

The calculation of GHGV includes contributions from storage, annual flux and the probable effects of large natural disturbances in the ecosystem (Fig. 2). The potential release of GHG from stored organic material (S, see Fig. 2) that would be released upon land clearing combines carbon that is released immediately through clearing of the aboveground vegetation, with carbon released over time through decomposition of litter and soil pools. In the year when the GHGV of a grid cell is determined, LPJ GUESS initiates $100 \%$ mortality of the existing vegetation, assuming that fire is used for the land clearing (see AT\&D11). This assumed 100\% consumption of the aboveground vegetation in a fire is not intended to represent a realistic method of land clearance but rather to ensure that the entire amount of carbon in an ecosystem is included in the calculation (see AT\&D11). In reality, we would expect some degree of inefficiency in the land clearance (whether it be by fire, or another method), which would leave a part of the aboveground vegetation biomass behind, which eventually would enter the soil pools. At $S(t=0)$, the aboveground living biomass and above ground litter are assumed to be fully consumed by the fire and oxidized immediately; roots are assigned to the litter pool.

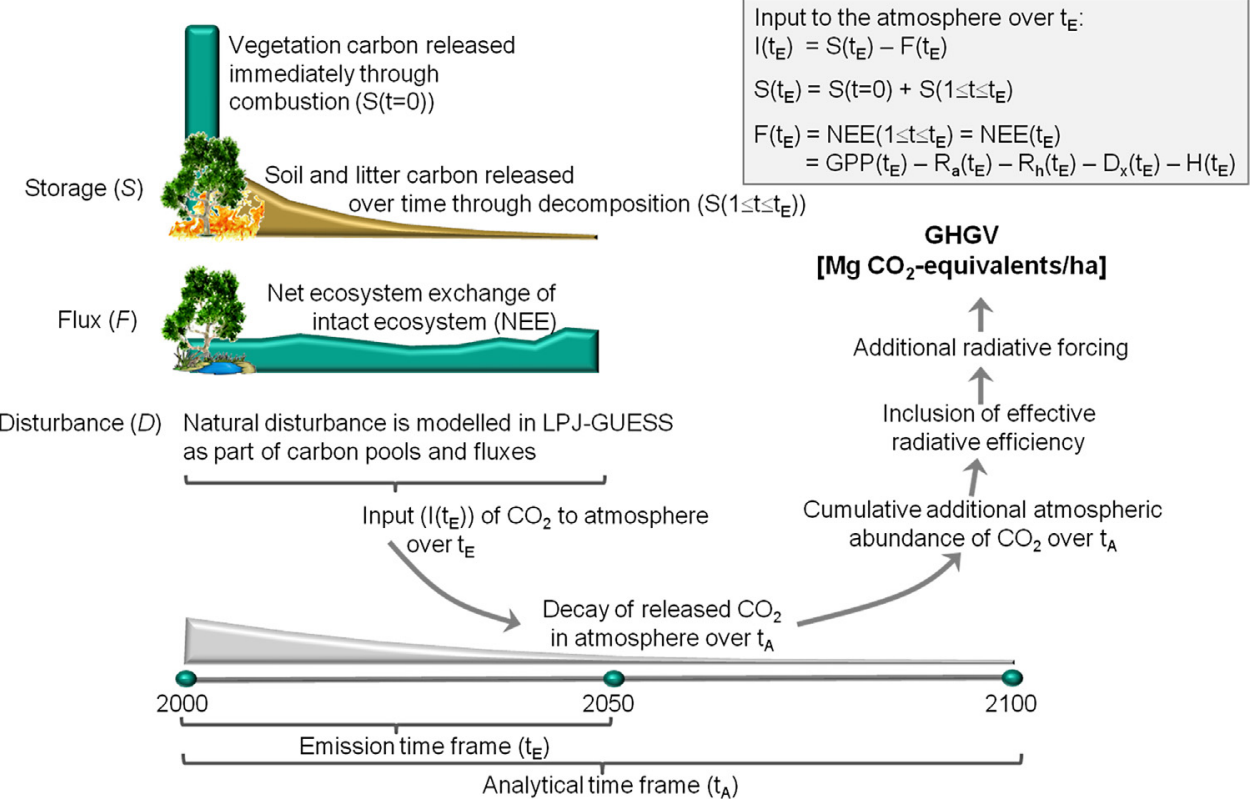

Fig. 2. Illustration of the derivation of $\mathrm{GHGV}$ (here: for $\mathrm{CO}_{2}$; example for $\mathrm{GHGV}_{2000}$ ). $\mathrm{GHGV}$ is made up of the individual contributions of $\mathrm{CO}_{2}$ exchanged with the atmosphere from stored carbon $(S)$, carbon flux $(F)$ and natural disturbances $(D)$, which are accounted for over the emission time frame $\left(t_{\mathrm{E}}\right)$ of 50 years and modeled with LPJ-GUESS. The contribution from storage $(S)$ is calculated assuming the complete destruction of the ecosystem by burning; upon which aboveground biomass is oxidized immediately $(S(t=0))$ and soil and litter carbon is released over $t_{\mathrm{E}}\left(S\left(1 \leq t \leq t_{\mathrm{E}}\right)\right)$. The annual flux of $\mathrm{CO}_{2}$ between the ecosystem and the atmosphere $(F)$ is the net ecosystem exchange $(N E E)$, the balance of the carbon taken up in photosynthesis (GPP), released through respiration $\left(R_{\mathrm{a}}\right)$, decomposition of organic material $\left(R_{\mathrm{h}}\right)$, natural fire and other disturbances $\left(D_{\mathrm{x}}\right)$, and, when accounting for land-use change, harvested material $(H)$. $S$ and $F$ (that intrinsically include $D$ in LPJ-GUESS simulations) are summed up to an input of $\mathrm{CO}_{2}$ to the atmosphere $\left(I\left(t_{\mathrm{E}}\right)\right)$ over $t_{\mathrm{E}}$. By application of a decay function over the analytical time frame $\left(t_{\mathrm{A}}\right)$ of 100 years and the radiative efficiency of $\mathrm{CO}_{2}$, this additional input of $\mathrm{CO}_{2}$ is converted to an additional radiative forcing that would arise from the destruction of the ecosystem. It is finally related to a pulse emission of $\mathrm{CO}_{2}$ and gives GHGV in $\mathrm{Mg} \mathrm{CO}_{2}$-equiv. ha ${ }^{-1}$. 
Vegetation is prevented from re growth after this assumed clearing and natural disturbance is disabled. Organic material in soil and litter pools continues to be released through heterotrophic respiration (Sitch et al., 2003) which gives $S\left(1 \leq t \leq t_{\mathrm{E}}\right.$ ).

The annual flux of GHGs from the ecosystem to the atmosphere ( $F$, see Fig. 2 ) represents the potential of an ecosystem to sequester or release GHGs. Here, it is calculated over the time period $t_{\mathrm{E}}$ for the non cleared, intact ecosystem. For $\mathrm{CO}_{2}$, the net ecosystem exchange (NEE, $F\left(1 \leq t \leq t_{\mathrm{E}}\right.$ ) is the balance of carbon taken up through photosynthesis (GPP) and $C$ released through respiration $\left(R_{\mathrm{a}}\right)$, decomposition of organic material $\left(R_{\mathrm{h}}\right)$, natural fire and other disturbances $\left(D_{\mathrm{x}}\right)$, and, when accounting for land use change, harvested material $(H)$. Positive values indicate a flux to the atmosphere. $F(t=0)$ is 0 by definition (see AT\&D11).

AT\&D11 approximate the effect of large, infrequent natural disturbances on GHGV $(D)$ by adjusting for the probabilistic impact of such events. In LPJ GUESS, large stand clearing forest fires, as the globally most important form of natural disturbance (Sitch et al., 2003), are modeled prognostically following Thonicke et al. (2001). Other forms of natural disturbance, such as insect outbreaks and wind throw are represented as a stochastic disturbance with an average 100 year return period. Therefore, in contrast to AT\&D11, contributions from these large, infrequent disturbances to GHGV are intrinsically accounted for in modeled carbon pools and fluxes that are the basis for calculations of $S$ and $F$.

For translating the contributions of $S$ and $F$ (including $D$ ) into GHGV, they are summed up for each year within the emission time frame $\left(I\left(t_{\mathrm{E}}\right)\right)$, giving the additional input of $\mathrm{CO}_{2}$ to the atmosphere if the ecosystem were to be destroyed (AT\&D11). By application of a decay function, this input of $\mathrm{CO}_{2}$ is converted to an additional atmospheric abundance of $\mathrm{CO}_{2}$ over the analytical time frame (which is typically longer than the emissions time frame $t_{\mathrm{E}}$; see Fig. 2). The additional radiative forcing resulting from this $\mathrm{CO}_{2}$ over $t_{\mathrm{A}}$ is calculated relative to a pulse emission of $\mathrm{CO}_{2}$, giving $\mathrm{GHGV}$ in $\mathrm{MgCO}_{2}$ equiv. ha ${ }^{-1}$; although only the contribution of $\mathrm{CO}_{2}$ to GHGV is considered here, GHGV is given in the original unit as defined by AT\&D11. The individual contributions of $S$ and $F$ to GHGV in units of GHGV are denoted by $C_{\mathrm{S}}$ and $C_{\mathrm{F}}$.

\subsection{Model simulations}

LPJ GUESS simulations are summarized in Table 1. Detailed information on input data is given in the Supplementary material. In brief, simulations were run at $0.5 \times 0.5^{\circ}$ resolution from 1850 to
2150 for three different implementations of LPJ GUESS (see Fig. 1): (1) potential natural vegetation (PNV), (2) including $C \mathrm{~N}$ coupling for potential natural vegetation $\left(\mathrm{PNV}_{\mathrm{N}}\right)$, and (3) LPJ GUESS with full crop and land use change representation (CLU). PNV simula tions give an estimate of biome average GHGV for ecosystems if the entire biome area would be in its potential natural state. This GHGV determined in PNV simulations can also be considered an estimate for natural land within biomes that also include a fraction under management. This perspective is expanded in $\mathrm{PNV}_{\mathrm{N}}$ simulations considering $\mathrm{C} \mathrm{N}$ dynamics. CLU simulations provide a biome average GHGV taking into account the current land use, where parts of the biome are pristine natural vegetation, while others are under different forms of agricultural land management. Results obtained from these two additional versions give a range of possible responses under anthropogenic land use and considering carbon nitrogen cycling.

Future projections (2006 2150) follow the most extreme representative concentration pathway (RCP) 8.5 for climate, $\mathrm{CO}_{2}$ mixing ratio, and land use projections. The low emission RCP 2.6 scenario was also considered for one simulation $\left(\mathrm{PNV}_{\mathrm{RCP}} 2.6\right)$, in order to cover a range of potential responses to climate change. The influence of climate, atmospheric $\mathrm{CO}_{2}$ mixing ratio and land use ( $\Delta \mathrm{CL}_{\mathrm{CLU}}, \Delta \mathrm{CO}_{2} \mathrm{CLU}$ and $\Delta \mathrm{LU}_{\mathrm{CLU}}$ ) was partitioned by determining the difference between the CLU simulation where all three drivers vary and three simulations $\left(\mathrm{CLU}_{\mathrm{CL}}, \mathrm{CLU}_{\mathrm{CO}_{2}}, \mathrm{CLU}_{\mathrm{LU}}\right)$ where one of the drivers was kept at the pre industrial level of 1850 (e.g. $\left.\Delta \mathrm{CL}_{\mathrm{CLU}}=\mathrm{CLU}-\mathrm{CLU}_{\mathrm{CL}}\right)$. Additional simulations were performed for PNV and $\mathrm{PNV}_{\mathrm{N}}$ model versions with all natural disturbance suppressed $\left(\mathrm{PNV}_{\mathrm{nd}}, \mathrm{PNV}_{\mathrm{N} \text { nd }}\right)$ and for PNV using the forcing of three other climate models $\left(\mathrm{PNV}_{\mathrm{MRI}}, \mathrm{PNV}_{\mathrm{HadGEM} 2}, \mathrm{PNV}_{\mathrm{IPSL}}\right)$ (see Table 1 ).

For each simulation, LPJ GUESS' modeled ecosystem carbon pools and fluxes were translated to quantify GHGV every 50 years from 1850 to 2100 . GHGV determined in the year 2000 was considered an approximation for the "current" GHGV of ecosys tems. For each set up, six simulations were required to determine the potential release of stored carbon $(S)$ for each time step, i.e. the vegetation of an ecosystem was simulated to be cleared in 1850 , $1900,1950,2000,2050$, and 2100 . The contribution of net carbon fluxes $(F)$ was calculated from simulations in which the artificial stand clearance that is used for determination of $S$ was not applied. This was one simulation for experiments without LULCC or where land use was fixed to year 1850 value $\left(\mathrm{PNV}, \mathrm{PNV}_{\mathrm{N}}, \mathrm{CLU}_{\mathrm{LU}}, \mathrm{PNV}_{\mathrm{nd}}\right.$, $\mathrm{PNV}_{\mathrm{N}}$ nd, $\mathrm{PNV}_{\mathrm{RCP}}$ 2.6, $\mathrm{PNV}$ for different climate model input). However, in experiments with varying land use (CLU, CLU $\mathrm{CL}_{\text {, }}$

Table 1

Overview of LPJ-GUESS simulations carried out as part of this study. See supplementary material for detailed information on input data.

\begin{tabular}{|c|c|c|c|c|c|c|c|c|c|}
\hline \multirow{2}{*}{$\begin{array}{l}\text { Future } \\
\mathrm{CL} / \mathrm{CO}_{2} \\
\text { pathway }\end{array}$} & \multirow{2}{*}{$\begin{array}{l}\text { Future LU } \\
\text { scenario }\end{array}$} & \multirow{2}{*}{$\begin{array}{l}\text { Climate } \\
\text { model }\end{array}$} & \multirow{2}{*}{$\begin{array}{l}\text { Simulation } \\
\text { acronym }\end{array}$} & \multirow[t]{2}{*}{ Sensitivities } & \multicolumn{3}{|c|}{ Environmental drivers } & \multirow{2}{*}{$\begin{array}{l}\mathrm{C}-\mathrm{N} \\
\text { coupling }\end{array}$} & \multirow{2}{*}{$\begin{array}{l}\text { Natural } \\
\text { disturbance } \\
\text { included }\end{array}$} \\
\hline & & & & & $\mathrm{CL}$ & $\mathrm{CO}_{2}$ & LU & & \\
\hline \multirow[t]{8}{*}{ RCP 8.5} & \multirow[t]{8}{*}{ RCP 8.5} & \multirow[t]{8}{*}{ MPI-ESM-LR } & PNV & Potential natural vegetation & Trans & Trans & n.i. & No & Yes \\
\hline & & & $\mathrm{PNV}_{\mathrm{N}}$ & $\begin{array}{l}\text { Potential natural vegetation } \\
\text { with C-N coupling }\end{array}$ & Trans & Trans & n.i. & Yes & Yes \\
\hline & & & CLU & $\begin{array}{l}\text { Full representation of croplands } \\
\text { and land-use change }\end{array}$ & Trans & Trans & Trans & No & Yes \\
\hline & & & $\mathrm{CLU}_{\mathrm{CL}}$ & CLU with constant climate & Fix & Trans & Trans & No & Yes \\
\hline & & & $\mathrm{CLU}_{\mathrm{CO}_{2}}$ & CLU with constant $\mathrm{CO}_{2}$ & Trans & Fix & Trans & No & Yes \\
\hline & & & $\mathrm{CLU}_{\mathrm{LU}}$ & CLU with constant land use & Trans & Trans & Fix & No & Yes \\
\hline & & & $\mathrm{PNV}_{\text {nd }}$ & $\begin{array}{l}\text { PNV with natural disturbance } \\
\text { suppressed }\end{array}$ & Trans & Trans & n.i. & No & No \\
\hline & & & $\mathrm{PNV}_{\mathrm{N}}$ nd & $\begin{array}{l}\mathrm{PNV}_{\mathrm{N}} \text { with natural disturbance } \\
\text { suppressed }\end{array}$ & Trans & Trans & n.i. & Yes & No \\
\hline RCP 2.6 & & & $\mathrm{PNV}_{\mathrm{RCP}} 2.6$ & PNV with RCP 2.6 climate & Trans & Trans & n.i. & No & Yes \\
\hline \multirow[t]{3}{*}{ RCP 8.5} & & MRI-CGCM3 & $\mathrm{PNV}_{\mathrm{MRI}}$ & PNV with MRI-CGCM3 climate & Trans & Trans & n.i. & No & Yes \\
\hline & & HadGEM2-ES & PNV $_{\text {HadGEM2 }}$ & PNV with HadGEM2-ES climate & Trans & Trans & n.i. & No & Yes \\
\hline & & IPSL-CM5A-MR & PNV $_{\text {IPSL }}$ & PNV with IPSL-CM5A-MR climate & Trans & Trans & n.i. & No & Yes \\
\hline
\end{tabular}

Abbreviations: $\mathrm{CL}$ : climate; $\mathrm{CO}_{2}$ : atmospheric carbon dioxide mixing ratio; $\mathrm{LU}$ : land use; trans: transient evolution of environmental driver; fix: environmental driver fixed to pre-industrial conditions (see Supplementary information); n.i.: parameter not included in respective model version. 
$\mathrm{CLU}_{\mathrm{CO}_{2}}$ ), calculation of $F$ required six simulations in which land use was held constant from the year of clearing over the entire $t_{\mathrm{E}}$ period, in order to evaluate the ecosystem based on its condition at the time of the clearing. Climate was allowed to vary, representing expected changes in climate.

The provision of GHGV was evaluated on a biome basis to account for the regionally disparate behavior of the terrestrial biosphere. Each half degree grid cell was assigned to a biome based on the leaf area index and the dominant PFT calculated by the model for natural vegetation (see Supplemen tary material).

LPJ GUESS determined GHGV of current ecosystems in their potential natural state $\left(\mathrm{GHGV}_{2000}\right.$ of PNV) were compared to GHGV estimates of an empirical modeling approach as given by AT\&D11. They base their GHGV estimates on measured data and comple mentary assumptions on organic matter stocks and GHG fluxes (obtained from reviews or primary studies) and the numerical representation of processes simulating the turnover of biomass and the release of GHGs in a stand clearing fire and when soil and litter carbon pools decompose. For each of the biomes considered here, AT\&D11 averaged between 1 and 32 measurements of carbon stocks and fluxes to obtain the average of $C$ stocks and fluxes from which GHGV was determined.

\section{Results}

\subsection{GHGV of ecosystems in their potential natural state}

GHGV in the year $2000\left(\mathrm{GHGV}_{2000}\right)$ simulated for ecosystems in their potential natural state (PNV simulation) was consistently positive, with the highest values simulated in tropical, boreal and temperate forests ( $>500 \mathrm{Mg} \mathrm{CO}_{2}$ equiv. ha ${ }^{-1}$, Figs. 3 and 4 and Table S3). Within these biomes, GHGV showed large variations driven by intra biome temperature gradients and variable precipitation, particularly across temperate and boreal forests. Dry and cold biomes had overall only small GHGV. For the non forest biomes in their potential natural state, GHGV below $250 \mathrm{Mg} \mathrm{CO}_{2}$ equiv. ha ${ }^{-1}$ were projected. Of these, GHGV of the tundra biome was highest because of significant carbon stocks in tundra soils (about $16 \mathrm{~kg} \mathrm{C} \mathrm{m}^{-2}$, Table S4). The sparsely vegetated desert biome aside, temperate grasslands were simulated to have lowest GHGV (average $109 \mathrm{Mg} \mathrm{CO}_{2}$ equiv. ha ${ }^{-1}$ ) corresponding to their low living biomass ( $5.5 \mathrm{~kg} \mathrm{C} \mathrm{m}^{-2}$ in total, Table S4). On average, over $90 \%$ of the total carbon amount in this biome is located in soils.

Over the historical period (GHGV of 1850 2000) GHGV of potential natural vegetation increased on global average by about

(a)

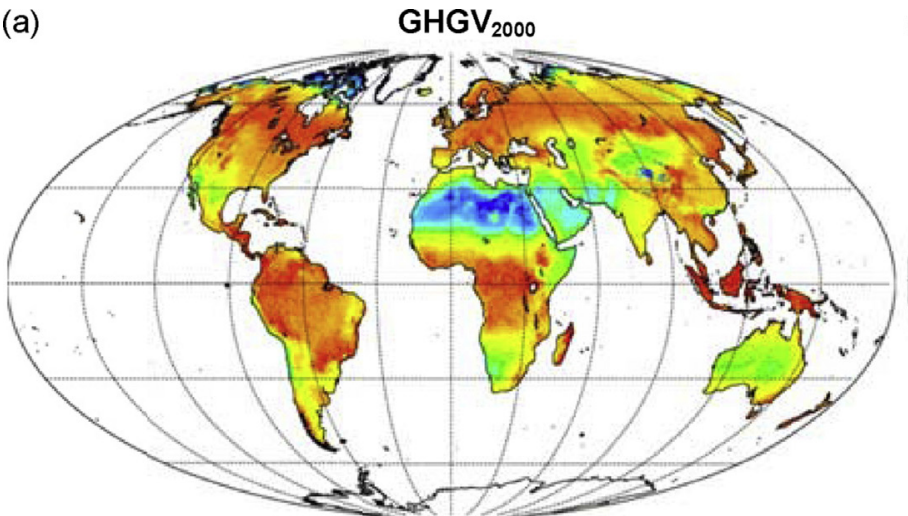

(b)
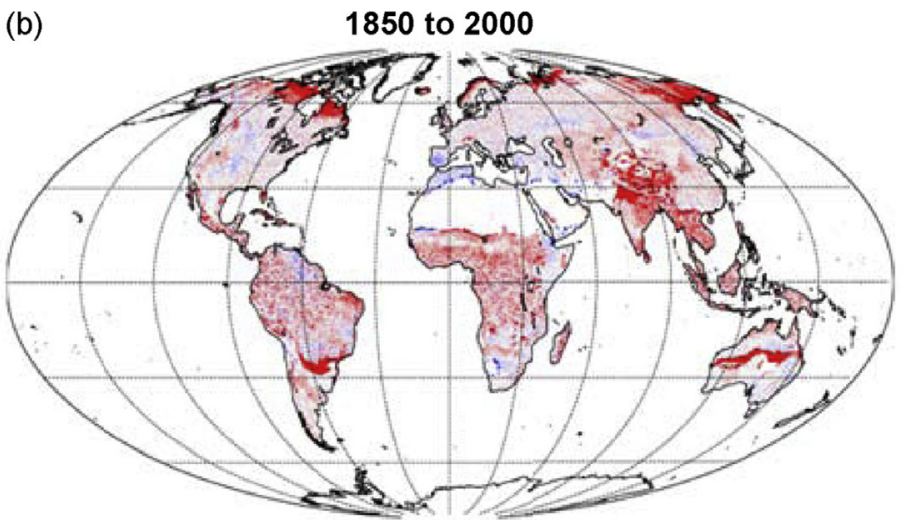

0 $10 \quad 100$

GHGV [Mg CO -equiv. ha $^{-1}$ ]

(c)

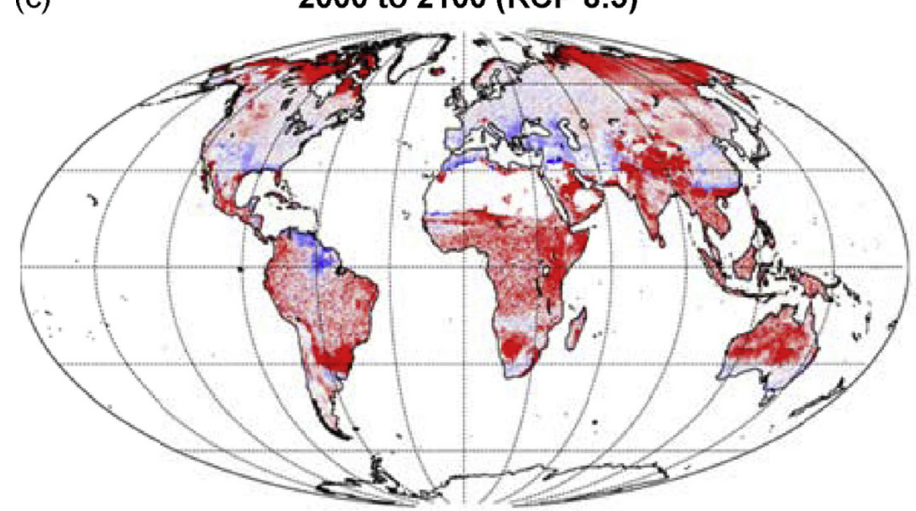

(d)
2000 to 2100 (RCP 2.6)

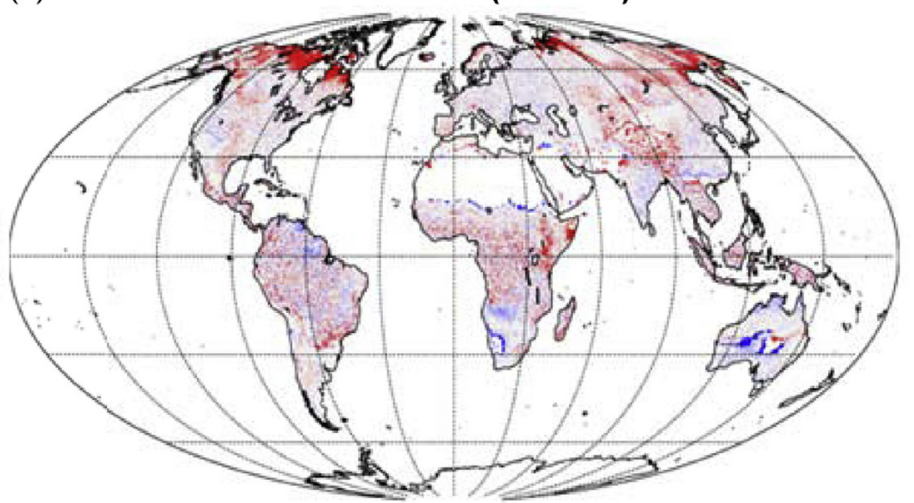

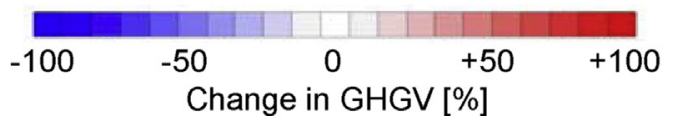

Fig. 3. Global GHGV for year 2000 [ $\mathrm{Mg} \mathrm{CO}_{2}$-equiv. ha $\left.{ }^{-1}\right]$ (a) and changes over the historical (b, 1850-2000) and future period (2000-2100) for RCPs 8.5 (c) and 2.6 (d). Values are given in \% of GHGV in 1850 (b) and 2000 (c, d). Results are shown for LPJ-GUESS simulation of potential natural vegetation (PNV for a-c and PNV $\mathrm{RCP}_{2.6}$ for d). Areas with GHGV values below $50 \mathrm{Mg} \mathrm{CO}_{2}$-equiv. ha ${ }^{-1}$ and their changes are excluded in (b)-(d) and also marked white. 

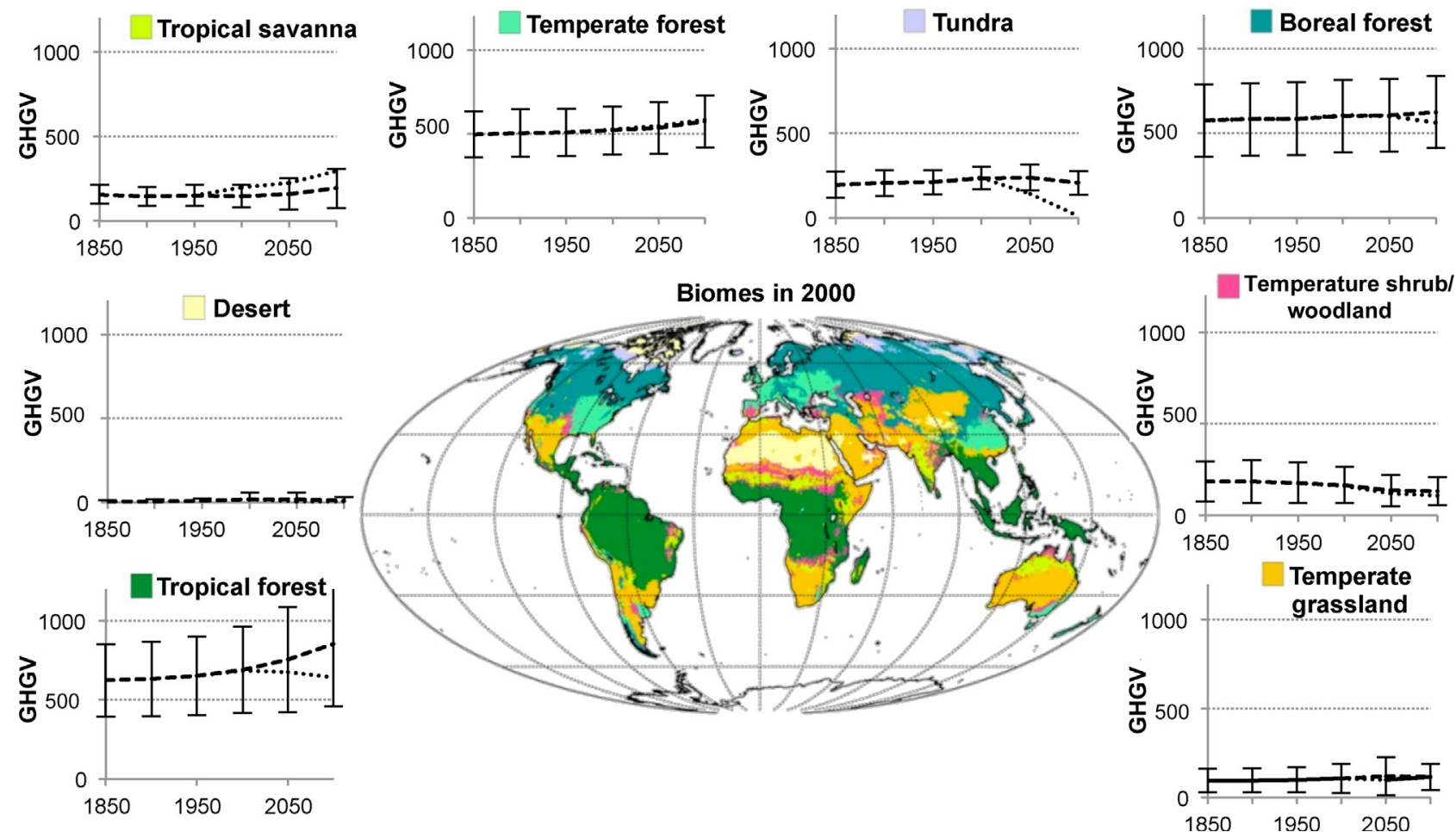

Fig. 4. Average GHGV for major biomes given with its standard deviation for LPJ-GUESS' simulation of natural ecosystems (PNV). Lines are drawn between GHGV derived every 50 years to visualize changes over time. Units are $\left[\mathrm{Mg} \mathrm{CO}_{2}\right.$-equiv. ha $\left.{ }^{-1}\right]$. The map shows biome distribution in year 2000 simulated by LPJ-GUESS. Future simulations were performed for RCP 8.5 (dashed lines, PNV) and RCP 2.6 (dotted lines, PNV $_{\text {RCP 2.6 }}$ ) (see Table 1).

$13 \%$ with small variations for individual biomes (Figs. 4 and 5 and Table S3). The three forest biomes were simulated to have a modest increase in GHGV of about $11 \%$ for tropical and of about $4 \%$ for temperate and boreal forests. The increase was attributed to rising atmospheric $\mathrm{CO}_{2}$ mixing ratios (see Section 4.2). The GHGV of tropical Savannas, and temperate shrub and woodlands decreased
( $-7 \%$ and $-10 \%$ respectively). Maps of GHGV over the historical period (Fig. 3b) showed a northward propagation of higher GHGV, i.e. in northern Canada and Siberia, due to increasing vegetation cover in these regions resulting from climate change induced higher temperatures and longer growing seasons (e.g. Sitch et al., 2008).
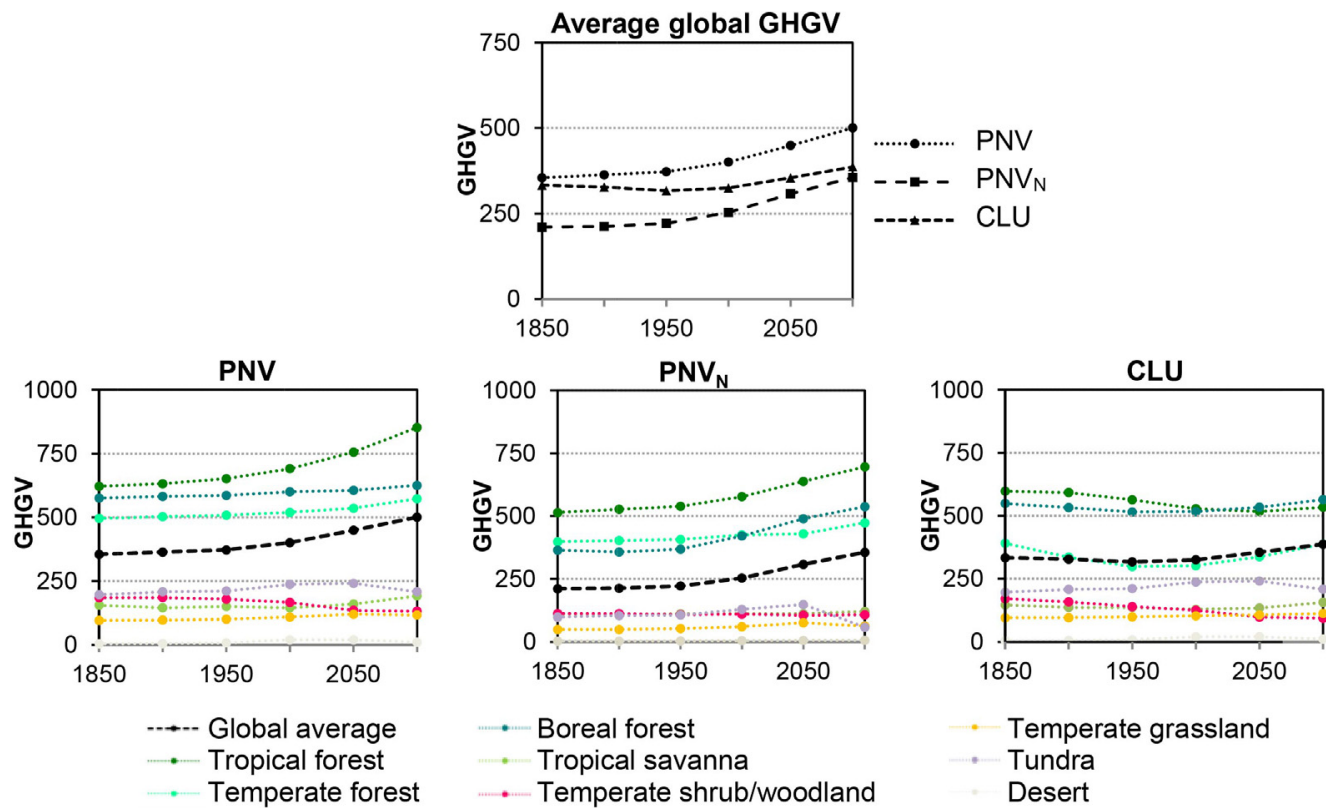

Fig. 5. Development of GHGV over historical and future periods predicted with LPJ-GUESS simulating potential natural vegetation (PNV), including coupled carbon and nitrogen cycling in PNV $\left(\mathrm{PNV}_{\mathrm{N}}\right)$, and representing croplands and land-use change (CLU) (see Table S3). Units are [Mg CO $\mathrm{CO}_{2}$-equiv. ha $\left.{ }^{-1}\right]$. Future simulations were performed for RCP 8.5 (see Table 1). 


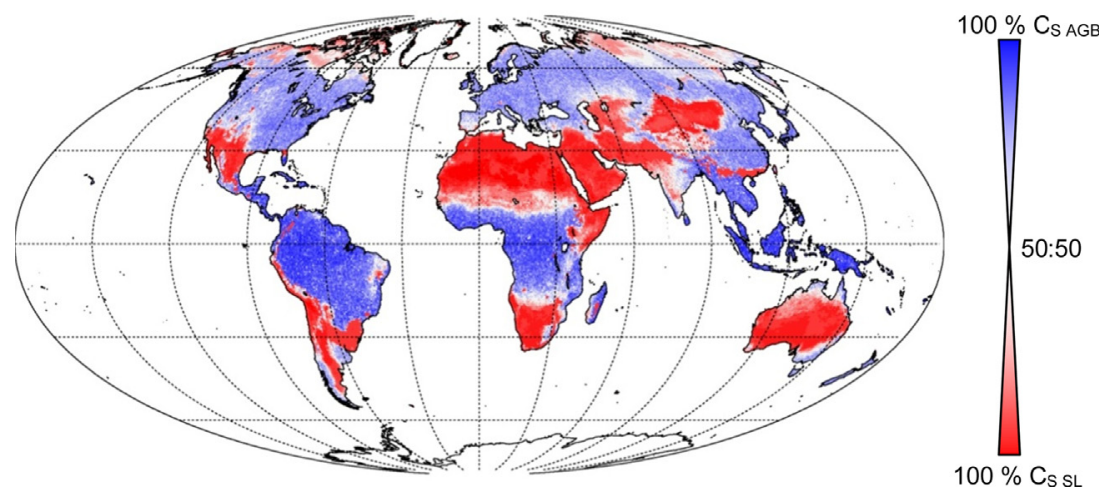

Fig. 6. The contribution from aboveground biomass $\left(C_{\mathrm{S}} \mathrm{AGB}\right)$ to the storage term $\left(C_{\mathrm{S}}\right)$ of GHGV is simulated to be highest in tropical forests. Apart from biomes with very low vegetation cover, the contribution of soil and litter carbon pools $\left(C_{\mathrm{S} \mathrm{SL}}\right)$ to $C_{\mathrm{S}}$ is simulated to increase in northern higher latitude forests and tundra. LPJ-GUESS simulations are for potential natural vegetation (PNV). $C_{\mathrm{S}} \mathrm{AGB}$ and $C_{\mathrm{S}} \mathrm{SL}$ are given as fractions of $C_{\mathrm{S}}$ [\%]. Map is shown for year 2000.

Over the 21st century, GHGV in natural ecosystems further increased by about $25 \%$ on global average relative to 2000 (Figs. 3c, 4 and 5, Table S3) when applying the high GHG emission scenario RCP 8.5 (see Section 2), a trend that was particularly pronounced in tropical forests due to the relatively enhanced $\mathrm{CO}_{2}$ fertilisation effects in warm climates (Hickler et al., 2008; Smith et al., 2014;Fig. 7b for CLU simulations). In temperate and boreal forests, by the end of the 21 st century, GHGV were nearly equal. GHGV of temperate shrub and woodlands declined from 2000 to 2100 . This decline at least partially results from the area covered by this biome expanding into tropical savanna or temperate grasslands. These latter biomes have lower GHGV than shrub and woodlands, and the period of time under the new vegetation type is too short for the soil carbon stocks to re equilibrate. However, a reduction in productivity caused by increased water stress may also play a role. The expansion of woody vegetation at the cost of grasses was an effect of the rising mixing ratio of $\mathrm{CO}_{2}$ in the atmosphere (data not shown; see also e.g. Mitchard and Flintrop, 2013). Under a low $\mathrm{CO}_{2}$ emission scenario (RCP 2.6), the increase in GHGV from 2000 to 2100 was only about $8 \%$ (PNV $_{\text {RCP } 2.6}$ simulation) (see Fig. S1, Table S5). In this case, the slow increase in $\mathrm{CO}_{2}$ induced increased productivity of the vegetation was nearly compensated by the effects of future climate change on the terrestrial carbon cycle, leading to a moderate increase in GHGV in most biomes under RCP 2.6 in comparison to the strong increase under RCP 8.5 (see Fig. 4). GHGV of tropical forests was significantly lower than under RCP 8.5 (Fig. 4, Fig. S1).

GHGV simulated for natural ecosystems with the coupled $\mathrm{C} \mathrm{N}$ implementation of LPJ GUESS $\left(\mathrm{PNV}_{\mathrm{N}}\right)$ were calculated to be about
$40 \%$ lower in year 2000 compared to the C only version (PNV) (Fig. 5, Table S3) because accounting for carbon nitrogen coupling considers the limitation of $\mathrm{CO}_{2}$ stimulated growth due to the absence of additional nitrogen (see Smith et al., 2014). On global average, nitrogen limitation lowered C stocks in vegetation by $25 \%$ and in soil and litter by $10 \%$ compared to C only simulations (see Smith et al., 2014). The comparison thus highlights important non linearities in the calculation of GHGV; the accounting of reduced carbon stocks and fluxes in the $\mathrm{C} \mathrm{N}$ version of the model, relative to the $\mathrm{C}$ only version, was amplified because of the exponential nature of the function accounting for released $\mathrm{CO}_{2}$ over $t_{\mathrm{A}}$ (AT\&D11). Nitrogen limitation most notably lowered carbon ES in boreal forests where cold temperatures limit rates of nitrogen mineralization, making trees less competitive against grasses (Wårlind et al., 2014). Over historical periods, the projected GHGV of boreal forests in the $\mathrm{C} \mathrm{N}$ version was lower than that of temperate forests. GHGV of tropical savanna, temperate shrub and woodland, and of the tundra biome were projected to be on a very similar level as for PNV in the carbon only version, around $100 \mathrm{Mg} \mathrm{CO}_{2}$ equiv. ha ${ }^{-1}$.

\subsection{GHGV under land use change}

Allowing for different land cover types and accounting for croplands and land use changes in LPJ GUESS simulations (CLU simulation) reduced the calculated GHGV for all biomes and for all considered time periods (Fig. 5, Table S3). Only in the desert biome were modeled carbon stocks and carbon sequestration slightly
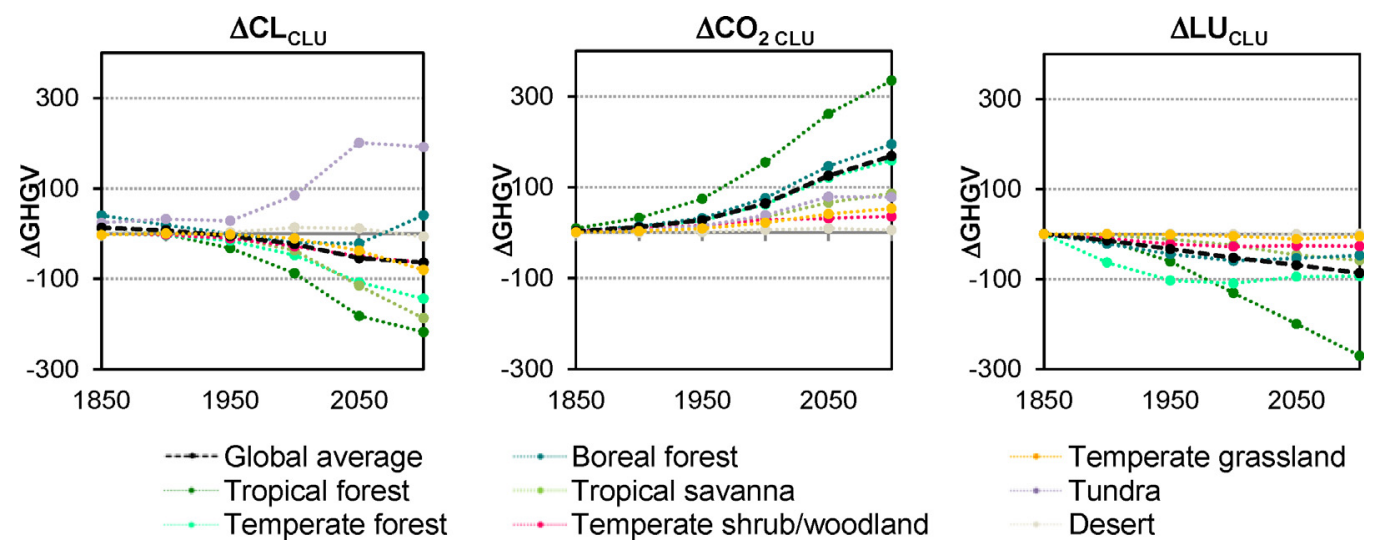

Fig. 7. Changes in GHGV due to variations of climate (CL), atmospheric $\mathrm{CO}_{2}\left(\mathrm{CO}_{2}\right)$, and land-use transitions (LU) alone for historical and future periods (e.g. $\Delta \mathrm{CL} \mathrm{CLU}_{\text {is }}$ the difference of CLU simulation and the $\mathrm{CLU}_{\mathrm{CL}}$ simulation where the driver climate is held at pre-industrial level). $\Delta \mathrm{GHGV}$ in 1850 differs from 0 because the calculation of GHGV includes ecosystem dynamics over 50 years (see Table S10). Units are $\left[\mathrm{Mg} \mathrm{CO}_{2}\right.$-equiv. ha $\left.{ }^{-1}\right]$. Future simulations were performed for RCP 8.5 (see Table 1 ). 

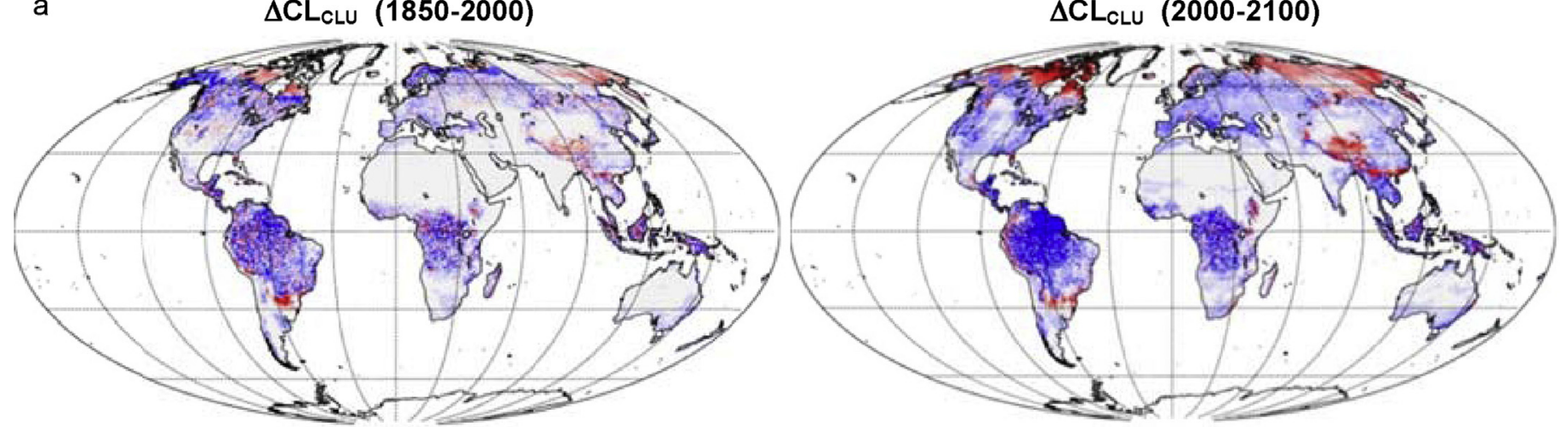

b

$\Delta \mathrm{CO}_{2} \mathrm{CLU}(1850-2000)$

$\Delta \mathrm{CO}_{2} \mathrm{CLU}(2000-2100)$
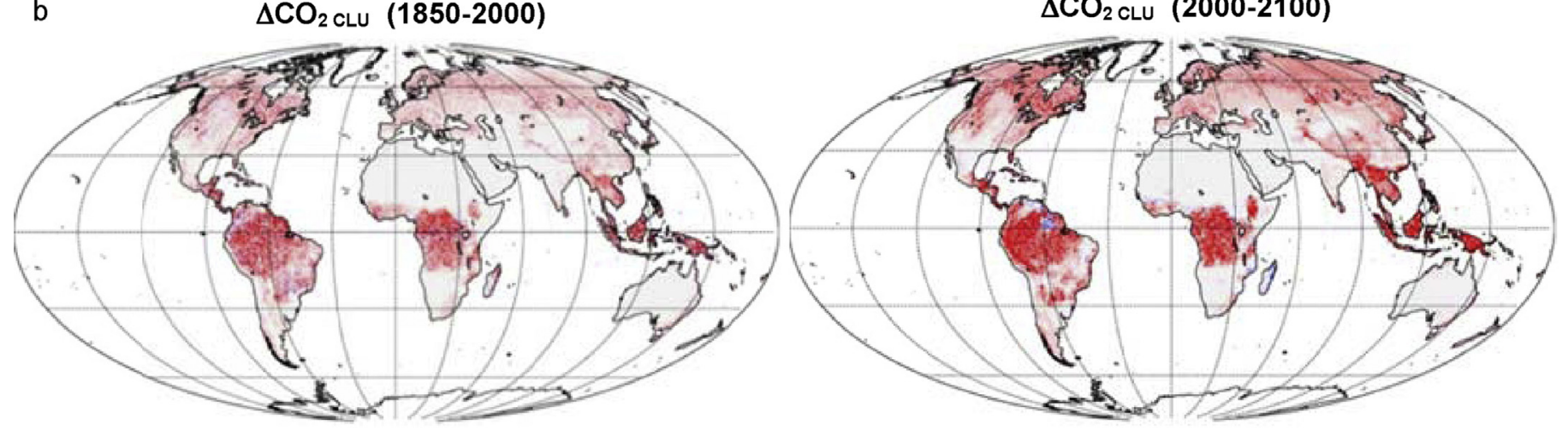

C

$\Delta L_{\text {CLU }}(1850-2000)$

$\Delta U_{\text {CLU }}(2000-2100)$
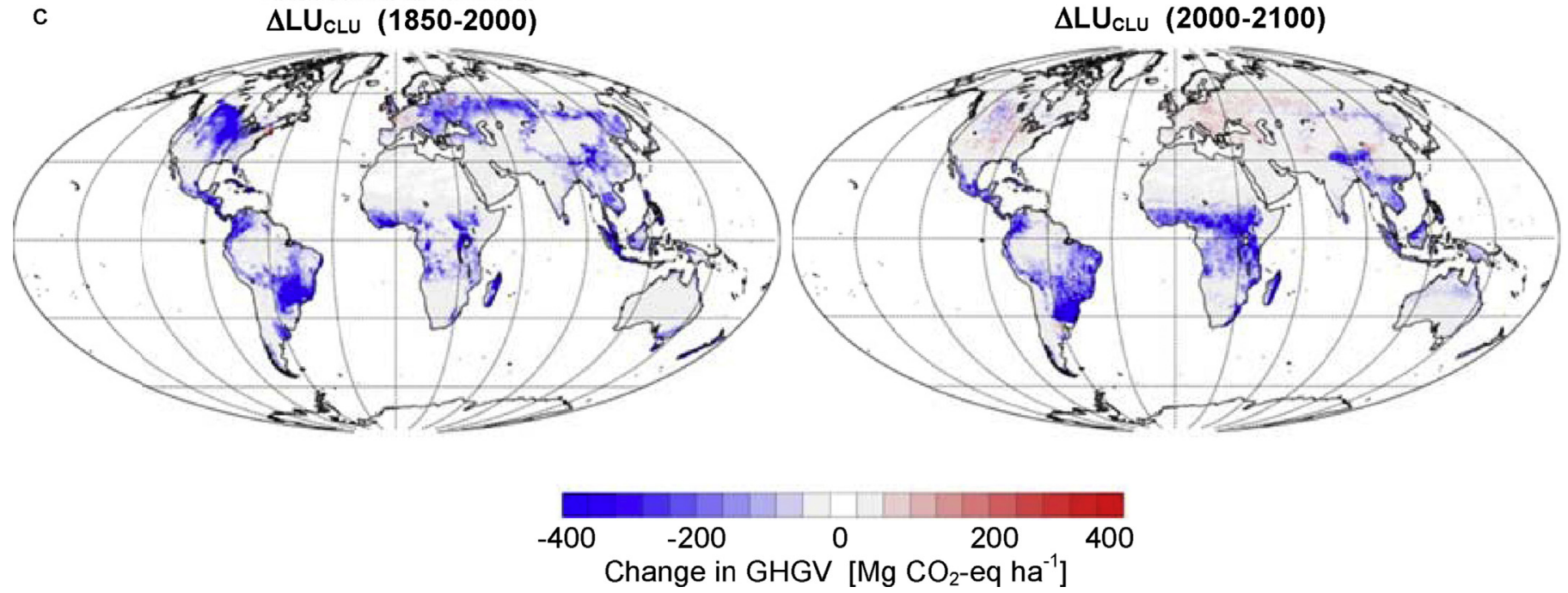

Fig. 8. Change in GHGV attributed to the environmental drivers climate $\left(\Delta \mathrm{CL}_{\mathrm{CLU}}\right)$ (a), atmospheric $\mathrm{CO}_{2}$ mixing ratio ( $\left.\Delta \mathrm{CO}_{2} \mathrm{CLU}\right)(\mathrm{b})$, and land use ( $\left.\Delta \mathrm{LU} \mathrm{CLU}_{\mathrm{Cu}}\right)(\mathrm{c})$ alone for historical (1850-2000, left column) and future periods (2000-2100, right column). Effects were determined using LPJ-GUESS' CLU simulations including croplands and land use change and simulations where each one driver is held at pre-industrial level. Future simulations were performed for RCP 8.5 (see Table 1 ).

increased through management practices such as irrigation, but GHGV were very low in these regions in any case. The CLU related decrease in GHGV, which on global average was $19 \%$ for ecosystems under present day conditions, resulted from the typically lower carbon stocks and carbon sequestration rate of agricultural systems compared to their natural equivalent (Table S4) (Guo and Gifford, 2002; McGuire et al., 2001). Regional trends in land use (Figs. 5, 7 and 8c, see also Section 4.2) substantially altered the simulated trends in GHGV for individual biomes (Fig. 5).

The increase of average global GHGV from pre industrial times until 2000 shown by PNV simulations, which was chiefly induced by an increased atmospheric $\mathrm{CO}_{2}$ mixing ratio, was canceled out when land use change was accounted for (Fig. 5, Table S3), so that the global average GHGV was almost constant over this period (Fig. 5). The initial expansion of agricultural area from 1850 onwards reduced GHGV until the middle of the 20th century (Fig. 5, Table S6). The loss in GHGV during this period was highest in temperate forests, due to a large conversion of natural forested areas to pastures and croplands in the land use change recon struction we used (increase of $15 \%$ and $13 \%$, Table S6). The rate of conversion of natural into agricultural lands leveled off by the end of the 20th century, especially in temperate and boreal forest biomes (Fig. 5, Table S6; Hurtt et al., 2011) when the increase in food demand was met by the intensification of production systems 
rather than expansion of production area (MEA, 2005). In the biomes dominated naturally by herbaceous vegetation cover, GHGV were similar with and without the consideration of LULCC.

At the beginning of the 21st century the negative effect of cropland establishment on GHGV was finally countered by the positive effect of $\mathrm{CO}_{2}$ (see also McGuire et al., 2001) (Table S3) and GHGV of CLU simulations on global average increased by $19 \%$ from 2000 to 2100 . GHGV of tropical forest remained nearly constant after 2000 (Fig. 5) because the continual deforestation in the applied land use scenario (loss of about $15 \%$ of forested area projected until 2100, Table S6) balanced the increase induced by $\mathrm{CO}_{2}$ fertilization (Fig. 7). In temperate forests, the negative trend of GHGV due to historical land use conversion was reversed by re forestation increasing the natural, i.e. forested, fraction from $46 \%$ in 2000 to 53\% in 2100 (Fig. 8c, Table S6, Hurtt et al., 2011). The GHGV of the boreal forest biome also increased due to re forestation but primarily due to increased productivity (see Section 3.1) (Fig. 7); in $2100 \mathrm{GHGV}$ of boreal forests was projected to exceed GHGV of tropical forests. As for the historical period, the net effect of LULCC on GHGV of the non forest biomes for future time periods was minor as, although significant land fractions were converted for agricultural land use, the carbon storage potential of the managed systems only marginally differed from the potential natural vegetation (Fig. 8c). These projections depend strongly on the combined climate, $\mathrm{CO}_{2}$, and land use change scenarios (Hurtt et al., 2011, see also development of $\mathrm{PNV}_{\mathrm{RCP}} 2.6$ in comparison to PNV, and Section 4.2).

\subsection{Components of GHGV}

In all simulations, GHGV was dominated by the contribution of stored organic matter $\left(C_{\mathrm{S}}\right.$, see Section 2$)$, rather than carbon fluxes $\left(C_{\mathrm{F}}\right.$, Fig. 4, Table S7). In particular the three forest biomes have high GHGV in all simulations because of their high carbon storage potential (19 $\mathrm{kg} \mathrm{C} \mathrm{m}^{-2}$ in tropical and temperate and $29 \mathrm{~kg} \mathrm{C} \mathrm{m}^{-2}$ in boreal forests, see Table S4). In tropical forests about 70\% of the carbon was simulated to be stored in vegetation biomass, while in boreal and temperate forests more than half of the carbon was stored in soil and litter pools (see Table S4). When the storage term of GHGV was split into fractions from the burning of aboveground biomass ( $\left.C_{\mathrm{S}} \mathrm{AGB}\right)$ and from the decomposition of soil and litter carbon pools ( $\left.C_{\mathrm{S} \mathrm{SL}}\right), C_{\mathrm{S} \mathrm{AGB}}$ accounted for more than two thirds of $C_{\mathrm{S}}$ ( $81 \%$ in tropical forests) for natural vegetation in the forest biomes (Fig. 6, Table S8). The large soil and litter carbon stocks in temperate and especially boreal forests contributed only $30 \%$ and $33 \%$ respectively to $C_{\mathrm{S}}$, because only part of the carbon in these pools was released over the considered emission time frame of 50 years; a longer term view might find these soil stocks to have a larger influence. Soil and litter pools only made up the majority of GHGV where aboveground carbon stocks were especially low, i.e. grasslands, tundra, and savanna (Fig. 6, Table S3). For simulations considering land management, the fraction of $C_{\mathrm{S}}$ AGB was slightly lower as a result of lower average aboveground biomass under partial cultivation, though it still accounted for the majority of $C_{\mathrm{S}}$ (CLU simulation in Table S8). The low influence of soil carbon was a result of the method for quantification of the carbon storage term that puts a higher weighting on carbon stored in aboveground biomass, as this is the carbon most vulnerable to loss during changes in the ecosystem. While $C_{\mathrm{S}}$ AGB mainly depends on the carbon pool sizes, $C_{\mathrm{S} S \mathrm{~L}}$ in addition is significantly influenced by the applied emission time frame $\left(t_{\mathrm{E}}\right)$ over which the released $\mathrm{CO}_{2}$ is assessed (see Section 2) and the modeled temperature and moisture dependent decomposition rates for soil and litter carbon. This emphasizes the importance of a long term perspective when assessing the influence of changes in land ecosystems on the climate system.
Contribution of the flux component $\left(C_{\mathrm{F}}\right)$ to GHGV was small (Table S7), but on average positive across all biomes (except for temperate forests under future climate) since natural ecosystems tend to be carbon sinks. One assumption of DGVMs is an equilibrium between carbon uptake and losses at the beginning of the modeling period with net ecosystem exchange averaging around zero by 1850 . This equilibrium is thereafter imbalanced by any changes of environmental forcings and carbon fluxes increase with time. Therefore, the relative influence of the flux component on GHGV increases until $\mathrm{GHGV}_{2100}$ (Table S7). A large variance in annual fluxes between the individual grid cells within a given biome results from the climatic variability across biomes (see also Le Quéré et al., 2013; Sitch et al., 2003, on the high spatial and temporal variability of NEE). Over a large area carbon fluxes cancel, so that biome wide averages of $C_{\mathrm{F}}$ are overall low with high standard deviations between 34 and $130 \mathrm{Mg} \mathrm{CO}_{2}$ equiv. ha ${ }^{-1}$ (Table S7).

Natural disturbance had a major influence on ecosystem GHGV. The exclusion of natural disturbance $\left(\mathrm{PNV}_{\mathrm{nd}}\right)$ increased biome GHGV in comparison to PNV simulations by over $90 \%$ in tropical forests, tropical savanna and temperate shrub and woodlands (for 2000 , see Tables S3 and S9), and by about 30\% in temperate and boreal forests. Effects are similar when considering $\mathrm{C} \mathrm{N}$ interac tions and land use and its changes. This is, however, a theoretical consideration, as ecosystem dynamics in these biomes are strongly linked to these episodic events (Hickler et al., 2004).

\section{Discussion}

The estimation of realistic GHGV depends to a large extent on the accurate determination of carbon stocks and fluxes, thus, evaluation of carbon stocks and fluxes serves as the basis for a qualitative evaluation of GHGV. LPJ GUESS's ability to represent carbon fluxes and their dynamics in response to climate and atmospheric $\mathrm{CO}_{2}$ were shown to be in the ranges provided by other DGVMs (e.g. Sitch et al., 2008, 2013), and were evaluated based on site measurements in Piao et al. (2013), and, including C N interactions, in Smith et al. (2014). Considering that the size of soil carbon stocks on a global scale is highly uncertain (see e.g. Todd Brown et al., 2013 in comparison to Pregitzer and Euskirchen, 2004), LPJ GUESS agrees with some evidence on carbon densities (e.g. on soil carbon from the Harmonized World Soil Database, FAO/IIASA/ISRIC/ISSCAS/JRC, 2012), that is consid erably better than is typical for ESMs (Todd Brown et al., 2013). Smith et al. (2014) showed that while mean global carbon fluxes and stocks of the base version of LPJ GUESS (PNV) are within the range that is spanned by observations, the agreement is slightly enhanced for the model version including $\mathrm{C} \mathrm{N}$ coupling $\left(\mathrm{PNV}_{\mathrm{N}}\right)$. The historical and future increase of global average carbon storage potential that leads to an increase in GHGV in our simulations of ecosystems in their potential natural state is consistent with projected changes in ecosystem carbon storage potential reported by other studies under a high emission scenario (Le Quéré et al., 2013; Sitch et al., 2013). The canceling out of the increase in GHGV when land use change was considered in the CLU simulations is in agreement with previous terrestrial $C$ balance calculations that included land use change (e.g. Arora and Boer, 2010; McGuire et al., 2001). The stagnant tropical GHGV in the late 20th and early 21st century (Fig. 5) as an effect of the balancing of deforestation and $\mathrm{CO}_{2}$ fertilization effects corresponds to atmospheric analyses and multi model projections which indicate that the tropics have been approxi mately carbon neutral during this time, whereas the ecosystems north of the tropics have been sinks for atmospheric carbon (McGuire et al., 2001; Prentice et al., 2000). 


\subsection{Comparison of GHGV from two independent modeling approaches}

LPJ GUESS derived GHGV of current natural ecosystems $\left(G_{H G V} 2000\right)$, excluding the effects of disturbance $\left(\mathrm{PNV}_{\mathrm{nd}}\right)$, were fairly close to GHGV estimates for the contribution of $\mathrm{CO}_{2}$ for natural ecosystems from the empirical modeling approach that was provided by AT\&D11 (Table S9, Fig. S2). Their GHGV estimates were provided without directly accounting for disturbance (term $D$, see Section 2, was not included) and were based on upscaling site scale observations of carbon stocks and fluxes. Recently disturbed forest sites were explicitly excluded from the AT\&D11 calculations of carbon stocks, however, for calculation of carbon fluxes, they included data from burned sites for fire adapted biomes. Therefore, their GHGV estimates only indirectly accounted for natural disturbance and comparisons with our estimates are thus difficult. With natural disturbance suppressed $\left(\mathrm{PNV}_{\mathrm{nd}}\right), \mathrm{LPJ}$ GUESS derived GHGV for ecosystems in their potential natural state increased substantially (see Tables S3 and S9). GHGV estimates of the empirical modeling approach are within or close to one standard deviation of LPJ GUESS derived GHGV (Fig. S2). Accounting for $\mathrm{C} \mathrm{N}$ interactions further improved the qualitative agreement between the two methods $\left(\mathrm{PNV}_{\mathrm{N} \text { nd }}\right.$ simulations, Table S9, Fig. S2). Only for temperate forests, where AT\&D11 estimated maximum GHGV, were LPJ GUESS simulated GHGV significantly lower (1572 vs. $663 \pm 224 \mathrm{Mg} \mathrm{CO}_{2}$ equiv. ha ${ }^{-1}$ in $\mathrm{PNV}_{\text {nd }}$ ). The deviation can be traced back to major differences in assumed carbon stocks of aboveground biomass $\left(9 \pm 3 \mathrm{~kg} \mathrm{C} \mathrm{m}^{-2}\right.$ simulated from LPJ GUESS, see Table S4, and $34 \pm 22 \mathrm{~kg} \mathrm{C} \mathrm{m}^{-2}$ given by AT\&D11 as estimate based on 32 sites). Small differences in carbon stock estimates of aboveground biomass exist also for other biomes, although they are below $\pm 3 \mathrm{~kg} \mathrm{C} \mathrm{m}^{-2}$. GHGV estimates for ecosys tems under partial management are not compared between the two approaches due to very different definitions of land use applied in our simulations compared to AT\&D11. Nevertheless, the lower GHGV predicted in the CLU simulations for biomes that are partially under agriculture is in line with lower GHGV estimates provided by AT\&D11 for five types of managed ecosystems. The above presented comparison of GHGV estimates is impaired by differences in model assumptions and biome classification between this study and AT\&D11 (e.g. on biomass carbon contents, burn characteristics, decay rates).

\subsection{Effects of drivers of environmental change on GHGV}

Changes in the GHGV presented in Section 3 are a major result of the drivers of climate, atmospheric $\mathrm{CO}_{2}$ mixing ratio, and land use. In order to elucidate this further, the net effects of these drivers of environmental change on GHGV were quantified from CLU simulations as the difference between simulations with these drivers variant and with drivers fixed to the pre industrial level (see Section 2 ). The impact of climate alone $\left(\Delta \mathrm{CL}_{\mathrm{CLU}}\right)$ exerted a modest decrease of GHGV for most biomes over historical and future time periods (Figs. 7 and 8a), which is up to $-17 \%$ in 2100 under RCP 8.5 (Table S10). In higher latitudes and mountainous regions (Fig. 8a), rising temperatures enhanced GHGV due to an expansion of vegetation into previously inhospitable regions, longer growing seasons and a higher productivity of plants in regions where plant photosynthesis so far occurred under temperatures below the optimum temperature range (see Fig. 3b, c). In most other biomes, and especially for future scenarios, LPJ GUESS simulates a somewhat reduced plant productivity with changing climate, as the optimum temperature ranges of PFTs are exceeded, leading to a net reduction of ecosystem GHGV (Fig. 5, Table S10). Losses were highest in ecosystems persisting under warm climates. Climate variability also includes highly regional changes in precipitation (IPCC, 2007b). Field studies and model experiments indicate a positive correlation between plant productivity and precipitation (e.g. Nepstad et al., 2002; Piao et al., 2013; Sitch et al., 2013) which would suggest a positive correlation with GHGV, although soil respiration rates may also increase with precipitation (Foley, 1995).

In contrast, rising atmospheric $\mathrm{CO}_{2}$ levels $\left(\Delta \mathrm{CO}_{2} \mathrm{CLU}\right)$, which are known to promote photosynthesis in $\mathrm{C} 3$ plants, thereby increasing vegetation, litter and soil carbon (e.g. Haxeltine and Prentice, 1996; Leakey et al., 2009; Smith and Dukes, 2013), consequently increased GHGV. This increase was on global average $20 \%$ of GHGV in 2000 and $44 \%$ in 2100 under RCP 8.5 (Table S10). Because of the temperature dependency of $\mathrm{CO}_{2}$ fertilization (Hickler et al., 2008), the effect was most pronounced in the low latitudes (i.e. tropical forests, tropical savannas, temperate shrub/woodlands, Figs. 7 and 8b) and slightly attenuated in the mid latitude forests.

The net effect of changes in land use $\left(\Delta L U_{C L U}\right)$ on global average GHGV was $-16 \%$ in 2000 and $-22 \%$ in 2100 (Table S10). These exact numbers were highly dependent on the applied land use scenario in combination with the representation of land use (croplands and pastures) in LPJ GUESS, since both notably change the carbon dynamics (analog to what has been shown elsewhere, e.g. Arora and Boer, 2010; McGuire et al., 2001). When considering the effects of land use changes with respect to inter biome differences, the storage potential of different carbon pools becomes highly relevant (Table S4). The vast majority of above ground vegetation biomass will be removed upon land conversion, and most of this carbon is rapidly oxidized and released to the atmosphere, i.e. when land is cleared by burning. Soil carbon stocks typically also deplete following conversion from natural ecosys tems to cropland, depending on management practices that influence soil carbon inputs, respiration rates and erosion such as residue removal and tillage (Lindeskog et al., 2013). Therefore, in the forest biomes the LPJ GUESS projected GHGV of agricultural ecosystems was significantly lower than of the simulated forest dominated native vegetation, while the impact of accounting for land use changes was small in grassland and woodland biomes (Figs. 5 and 8c, Table S3). Here, the potential loss of above ground carbon upon conversion to cropland was relatively small and the carbon storage potential of the crops that are grown was similar to the one of the prevailing natural vegetation. The latter result is, however, highly dependent on agricultural management choices.

\subsection{Uncertainties in LPJ GUESS estimates of GHGV}

LPJ GUESS provides a globally consistent framework for calculating GHGV that uses process based mechanisms to account for the effect of spatially and temporally varying environmental conditions on ecosystem processes. GHGVs and their changes presented in this study provide realistic assessments, though exact numbers are highly dependent on the applied scenarios of climate, atmospheric mixing ratio, and land use (see e.g. results for RCPs 8.5 and 2.6 in Section 3.1). There is a considerable variance in the ecosystem responses to environmental changes simulated by land surface models (e.g. Piao et al., 2013; Sitch et al., 2013). Besides the uncertainty introduced by climate model input (Ahlström et al., 2012; Ciais et al., 2013), the observed model to model discrepancy results from simplified process representation and/or because of a poor understanding of important processes (Arneth et al., 2010; Smith and Dukes, 2013). For instance, most models assume an equilibrium of carbon fluxes at the beginning of the modeling period in pre industrial times, even though substantial land use changes had occurred already before 1850 (e.g. Klein Goldewijk et al., 2011; Kaplan et al., 2011). Moreover, by applying a DGVM the representations of relevant processes are necessarily optimized for 
the global and regional scale, and the values derived can thus not easily be compared to local scale studies.

Recent multi model experiments show a good agreement of models on the immediate effects of enhanced atmospheric $\mathrm{CO}_{2}$ mixing ratio on photosynthesis (see e.g. Sitch et al., 2008, 2013; McGuire et al., 2001) that follow the evidence from most FACE experiments (e.g. Piao et al., 2013). However, on the long term there is evidence that the state of the art models suffer from insufficient representation of C N interactions (Zaehle et al., 2014), for instance the representation of tissue growth (Fatichi et al., 2014). The simulated impacts of climate changes on net primary productivity (NPP) and decomposition vary greatly as a result of differences in process representations between vegetation models, and because of different climate model inputs (see e.g. Sitch et al., 2008, 2013; McGuire et al., 2001). Nonetheless, although the $\mathrm{PNV}_{\mathrm{N}}$ simulations produced lower GHGV across many biomes, they did not notably dampen the positive trend in GHGV due to $\mathrm{CO}_{2}$ fertilization that was observed in the simulations without $\mathrm{N}$ limitation.

Additional simulations of PNV using four instead of only one climate model (PNV, PNV $\mathrm{MRI}_{\text {I }}$ PNV HadGEM2 $_{\text {, and }} \mathrm{PNV}_{\text {IPSL, }}$, see Section 2 ) indicate deviations between $-93 \mathrm{Mg} \mathrm{CO}_{2}$ equiv. ha ${ }^{-1}$ and $+170 \mathrm{MgCO}_{2}$ equiv. ha ${ }^{-1}$ for future periods for individual biomes (GHGV in 2100; Table S11). Whilst substantial, these differences are not sufficient to change the conclusions of this study. The variation of GHGV due to different climate model input is small for the historical period (not shown) since all climate data used here was bias corrected to observational climate (see Supplementary material).

\section{Conclusions}

This study extends the calculation of GHGV pioneered by AT\&D11 to consider both its evolution over time, and the global scale. Results show a close coupling between GHGV and the environmental drivers of climate, atmospheric $\mathrm{CO}_{2}$ mixing ratio, land use, and nitrogen availability. They further demonstrate the importance of accounting for large, infrequent, natural distur bances in simulations of the terrestrial carbon cycle and notably for the calculation of realistic GHGV, particularly as disturbance regimes may change in the future (Seidl et al., 2014). Natural disturbances are likely to be missed or under sampled in estimations of GHGV scaled up from forest plots, unless careful precautions are taken. A realistic assessment of all factors influencing GHGV is particularly important in consideration of the non linearities inherent in the conversion of carbon stocks and fluxes into GHGV. This study provides a demonstration of possible response of GHGV to environmental change, although the exact numbers vary with the representation of additional ecosystem processes and nutrient cycles in the model, and with the applied scenarios of environmental drivers.

In the simulations presented herein, generally high biome average GHGV ( $>300 \mathrm{MgCO}_{2}$ equiv. ha ${ }^{-1}$ ), and a significant reduction of GHGV when agriculture was simulated, emphasized the role of forest biomes for ecosystem carbon sequestration. A clear imperative therefore emerges to preserve and restore the forest biomes which contain large stocks of above ground biomass. Soil carbon stocks need long timescales to accumulate, and significant losses from these pools are only reversible on time scales of centuries. In contrast, above ground biomass stocks will in many cases recover more quickly in the event of reforestation. This suggests that maintaining and increasing carbon sequestra tion over the next century will be most successful under a management scenario which is concentrated on the forest biomes. The significant increase in GHGV that was projected for undis turbed forests under strong increases in future climate forcing and
$\mathrm{CO}_{2}$ mixing ratios ( $\mathrm{RCP} 8.5$ ) was especially large in tropical forests. However, under the RCP 8.5 land use projection used here, this increase was canceled out by ongoing deforestation. It should be noted that this is not an extreme deforestation scenario. In addition, this analysis did not extend to tropical peatlands, which may hold substantial carbon deposits.

The Greenhouse Gas Value of Ecosystems is a valuable indicator for quantifying the full implications of carbon sequestration, as it considers, besides the potential of an ecosystem to sequester carbon, also the amount of carbon that it has already sequestered, and the modification of these properties by episodic disturbances. Its quantification in $\mathrm{Mg} \mathrm{CO}_{2}$ equiv. ha ${ }^{-1}$ is a standard unit that provides the basis for comparing the effects of different GHGs on climate (IPCC, 2007b), and can be used to place monetary values on ecosystems by multiplying it with the market price of carbon $\left(\$ \mathrm{Mg} \mathrm{CO}_{2}\right.$ equiv. $\left.^{-1}\right)$. GHGV of carbon dioxide accounts for the vast majority of GHG emissions from decomposition of organic material in natural ecosystems and partially cultivated areas, with the exception of wetlands or peatlands, which potentially have significant methane fluxes (Schulze et al., 2009), and of $\mathrm{N}_{2} \mathrm{O}$ emissions from agriculture. The inclusion of these non $\mathrm{CO}_{2}$ greenhouse gases in models will yield a more comprehensive GHGV calculation and should be a priority for future assessments. Nonetheless, when determining the value of ecosystems, in particular to achieve better management decisions, GHGV is only one aspect of ecosystems, and has to be considered in association with other ecosystem services (e.g. water supply and water quality, production of food, fodder, fiber and fuel, regulation of water flows, and pollination).

\section{Acknowledgements}

The authors thank Ben Smith and David Wårlind from Lund University for advice on biome classification and the nitrogen version of LPJ GUESS. They further acknowledge the World Climate Research Program's Working Group on Coupled Modeling, which is responsible for CMIP, and thank the climate modeling groups for producing and making available their model output. This work was funded by the European Commission's 7th Framework Program under Grant Agreement numbers 308393 (OPERAs) and 603542 (LUC4C). AA acknowledges support from the HGF Initiative and Networking Fund. This work was supported, in part, by the German Federal Ministry of Education and Research (BMBF), through the Helmholtz Association and its research program ATMO.

\section{References}

Ahlström, A., Schurgers, G., Arneth, A., Smith, B., 2012. Robustness and uncertainty in terrestrial ecosystem carbon response to CMIP5 climate change projections. Environ. Res. Lett. 7, 044008.

Anderson-Teixeira, K., DeLucia, E., 2011. The greenhouse gas value of ecosystems. Global Change Biol. 17, 425-438.

Anderson-Teixeira, K., Snyder, P., Twine, T.E., Cuadra, S., Costa, M., DeLucia, E., 2012. Climate-regulation services of natural and agricultural ecoregions of the Americas. Nat. Clim. Change 2, 177-181.

Arneth, A., Harrison, S., Zähle, S., Tsigaridis, K., Menon, S., Bartlein, P., Feichter, J., Korhola, A., Kulmala, M., O'Donnell, D., Schurgers, G., Sorvari, S., Vesala, T., 2010. Terrestrial biogeochemical feedbacks in the climate system. Nat. Geosci. 3, 525532

Arora, V.K., Boer, G.J., 2010. Uncertainties in the 20th century carbon budget associated with land use change. Global Change Biol. 16, 3327-3348.

Bondeau, A., Smith, P.C., Zähle, S., Schaphoff, S., Lucht, W., Cramer, W., Gerten, D., Lotze-Campen, H., Müller, C., Reichstein, M., Smith, B., 2007. Modelling the role of agriculture for the 20th century global terrestrial carbon balance. Global Change Biol. 13, 679-706. 
Bugmann, H., 2001. A review of forest gap models. Clim. Change 51, 259-305. CCX, 2009. Chicago Climate Exchange General Offset Program Provisions. Chicago Climate Exchange Inc., Chicago, IL, USA.

Ciais, et al., 2013. Carbon and other biogeochemical cycles. In: Stocker, T.F., Qin D., Plattner G.-K., Tignor M., Allen S.K., Boschung J., Nauels A., Xia Y., Bex V., Midgley P.M., (Eds.), Climate Change 2013: The Physical Science Basis. Contribution of Working Group I to the Fifth Assessment Report of the Intergovernmental Panel on Climate Change. Cambridge University Press, Cambridge, United Kingdom/ New York, USA, 1535 pp. (Chapter 6).

FAO/IIASA/ISRIC/ISSCAS/JRC, 2012. Harmonized World Soil Database (version 1.10) FAO/IIASA, Rome, Italy/Laxenburg, Austria.

Fatichi, S., Leuzinger, S., Körner, C., 2014. Moving beyond photosynthesis: from carbon source to sink-driven vegetation modeling. New Phytol. 201, 10861095.

Foley, J.A., 1995. An equilibrium model of the terrestrial carbon budget. Tellus 47B, 310-319.

Guo, L.B., Gifford, R.M., 2002. Soil carbon stocks and land use change: a meta analysis. Global Change Biol. 8, 345-360.

Haines-Yong, R., Potschin, M., 2013. CICES V4.3 - Revised Report Prepared Following Consultation on CICES Version 4, August-December 2012. EEA Framework Contract No EEA/IEA/09/003.

Haxeltine, A., Prentice, I.C., 1996. A general model for the light-use efficiency of primary production. Funct. Ecol. 10, 551-561.

Hickler, T., Smith, B., Sykes, M.T., Davis, M.B., Walker, K., Sykes, M.T., Sugita, S., 2004. Using a generalized vegetation model to simulate vegetation dynamics in northeastern USA. Ecology 85, 519-530.

Hickler, T., Prentice, C.I., Smith, B., Sykes, M.T., Zaehle, S., 2006. Implementing plant hydraulic architecture within the LPJ dynamic global vegetation model. Global Ecol. Biogeogr. 15, 567-577.

Hickler, T., Smith, B., Prentice, I.C., Mjofors, K., Miller, P., Arneth, A., Sykes, M.T., 2008 $\mathrm{CO}_{2}$ fertilization in temperate FACE experiments not representative of boreal and tropical forests. Global Change Biol. 14, 1531-1542.

Hickler, T., Vohland, K., Feehan, J., Miller, P.A., Smith, B., Costa, L., Giesecke, T. Fronzek, S., Carter, T.R., Cramer, W., Kühn, I., Sykes, M.T., 2012. Projecting the future distribution of European potential natural vegetation zones with a generalized, tree species-based dynamic vegetation model. Global Ecol. Biogeogr. 21, 50-63.

Hurtt, G.C., Chini, L.P., Frolking, S., Betts, R.A., Feddema, J., Fischer, G., Fisk, J.P., Hibbard, K., Houghton, R.A., Janetos, A., Jones, C.D., Kindermann, G., Kinoshita, T., Klein Goldewijk, K., Riahi, K., Shevliakova, E., Smith, S., Stehfest, E., Thomson, A., Thornton, P., van Vuuren, D.P., Wang, Y.P., 2011. Harmonization of land-use scenarios for the period 1500-2100: 600 years of global gridded annual landuse transitions, wood harvest, and resulting secondary lands. Clim. Change 109, $117-161$.

IPCC, 2006. Agriculture, forestry and other land use. In: Eggleston, H.S., Buendia, L. Miwa, K., Ngara, T., Tanabe, K. (Eds.), 2006 IPCC Guidelines for National Greenhouse Gas Inventories. Institute for Global Environmental Strategies, Hayama, Japan.

IPCC, 2007a. In: Solomon, S., Qin, D., Manning, M., Marquis, M., Averyt, K.B., Tignor, M.M.B., Miller, H.L., Chen, Z. (Eds.), Climate Change 2007: The Physical Science Basis. Contribution of Working Group I to the Fourth Assessment Report of the Intergovernmental Panel on Climate Change. Cambridge University Press, United Kingdom/New York, NY, USA, 996 pp.

IPCC, 2007b. Climate change 2007: synthesis report. In: Pachauri, R.K., Reisinger, A (Eds.), Contribution of Working Groups I, II and III to the Fourth Assessment Report of the Intergovernmental Panel on Climate Change. IPCC.

Kaplan, J.O., Krumhardt, K.M., Ellis, E.C., Ruddiman, W.F., Lemmen, C., Goldewijk, K.K., 2011. Holocene carbon emissions as a result of anthropogenic land cover change. The Holocene 21, 775-791, http://dx.doi.org/10.1177/095968 3610386 983.

Klein Goldewijk, K., Beusen, A., Van Drecht, G., De Vos, M., 2011. The HYDE 3.1 spatially explicit database of human-induced global land-use change over the past 12,000 years. Glob. Ecol. Biogeogr. 20, 73-86, http://dx.doi.org/10.1111/ j.1466-8238.2010.00587x

Lal, R., 2004. Soil carbon sequestration to mitigate climate change. Geoderma 123, $1-22$

Le Quéré, C., Peters, G., Andres, R., Andrew, R., Boden, T., Ciais, P., Friedlingstein, P., Houghton, R., Marland, G., Moriarty, R., Sitch, S., Tans, P., Arneth, A., Arvanitis, A. Bakker, D., Bopp, L., Canadell, J., Chini, L., Doney, S., Harper, A., Harris, I., House, J. Jain, A Jones, S, Kato, E., Keeling R, Klein Goldewijk, K, Körtzinger, A. Koven, C., Lefèvre, N., Omar, A., Ono, T., Park, G.-H., Pfeil, B., Poulter, B., Raupach, M., Regnier, P., Rödenbeck, C., Saito, S., Schwinger, J., Stocker, B., Tilbrook, B., van Heuven, S., Viovy, N., Wanninkhof, R., Wiltshire, A., Zaehle, S., Yue, C., 2013. Global carbon budget 2013. Earth Syst. Sci. Data Discuss. 6, 689-760.

Leakey, A.D.B., Ainsworth, E.A., Bernacchi, C.J., Rogers, A., Long, S.P., Ort, D.R., 2009. Elevated $\mathrm{CO}_{2}$ effects on plant carbon, nitrogen, and water relations: six important lessons from FACE. J. Exp. Bot. 60, 2859-2876, http://dx.doi.org/10.1093/ jxb/erp096.

Lindeskog, M., Arneth, A., Bondeau, A., Waha, K., Seaquist, J., Olin, S., Smith, B., 2013. Implications of accounting for land use in simulations of ecosystem services and carbon cycling in Africa. Earth Syst. Dyn. Discuss. 4, 235-278.

McGuire, A.D., Sitch, S., Clein, J.S., Dargaville, R., Esser, G., Foley, J., Heimann, M., Joos, F, Kaplan, J. Kicklighter, D.W Meier, RA, Melillo, JM. Moore III, JM. Prentice, I.C. Ramankutty, N., Reichenau, T., Schloss, A., Tian, H., Williams, LJ. Wittenberg, U., 2001. Carbon balance of the terrestrial biosphere in the twentieth century: analyses of $\mathrm{CO}_{2}$, climate and land use effects with four process-based ecosystem models. Global Biogeochem. Cycles 15, 183-206.

Miles, L., Kapos, V., 2008. Reducing greenhouse gas emissions from deforestation and forest degradation: global land-use implications. Science 320, 1454-1455.

Millennium Ecosystem Assessment (MEA), 2005. Ecosystems and Human Wellbeing: Synthesis. Island Press, Washington, DC.

Mitchard, E.T.A., Flintrop, C.M., 2013. Woody encroachment and forest degradation in sub-Saharan Africa's woodlands and savannas 1982-2006. Philos. Trans. R. Soc. 368.

Morales, P., Sykes, M.T., Prentice, I.C., Smith, P., Smith, B., Bugmann, H., Zierl, B., Friedlingstein, P., Viovy, N., Sabate, S., Sanchez, A., Pla, E., Gracia, C.A., Sitch, S., Arneth, A., Ogee, J., 2005. Comparing and evaluating process-based ecosystem model predictions of carbon and water fluxes in major European forest biomes. Global Change Biol. 11, 2211-2233.

Nepstad, D., Moutinho, P., Dias-Filho, M., Davidson, E., Cardinot, G., Markewitz, D., Figueiredo, R., Vianna, N., Chambers, J., Ray, D., Guerreiros, J., Lefebvre, P., Sternberg, L., Barros, M.M., Ishida, L., Tohlver, F., Belk, I., Kalif, E., Schwalbe, K.K., 2002. The effects of partial throughfall exclusion on canopy processes, aboveground production, and biogeochemistry of an Amazon forest. J. Geophys. Res. 107, 8085

Piao, S., Sitch, S., Ciais, P., Friedlingstein, P., Peylin, P., Wang, X., Ahlström, A., Anav, A. Canadell, J., Cong, N., Huntingford, C., Jung, M., Levis, S., Levy, P.J., Lin, L. Lomas, X., Lu, M., Luo, M., Ma, Y., Myneni, Y., Poulter, R., Sun, B., Wang, Z., Viovy, T., Zaehle, N., Zeng, S.N., 2013. Evaluation of terrestrial carbon cycle models for their response to climate variability and to $\mathrm{CO}_{2}$ trends. Global Change Biol. 19, 2117-2132.

Pregitzer, K.S., Euskirchen, E.S., 2004. Carbon cycling and storage in world forests: biome patterns related to forest age. Global Change Biol. 10, 2052-2077, http:// dx.doi.org/10.1111/j.1365-2486.2004.00866.x.

Prentice, I.C., Heimann, M., Sitch, S., 2000. The carbon balance of the terrestrial biosphere: ecosystem models and atmospheric observations. Ecol. Appl. 10, 1553-1573.

Schulze, E., Luyssaert, S., Ciais, P., Freibauer, A., Janssens, I., Soussana, J., Smith, P., Grace, J., Levin, I., Thiruchittampalam, B., Heimann, M., Dolman, A., Valentini, R., Bousquet, P., Peylin, P., Peters, W., Rödenbeck, C., Etiope, G., Vuichard, N., Wattenbach, M., Nabuurs, G., Poussi, Z., Nieschulze, J., Gash, J., the CarboEurope Team, 2009. Importance of methane and nitrous oxide for Europe's terrestrial greenhouse-gas balance. Nat. Geosci. 2, 842-850

Seidl, R., Schelhaas, M., Rammer, W., Verkerk, P.J., 2014. Increasing forest disturbances in Europe and their impact on carbon storage. Nat. Clim. Change 4, 806810, http://dx.doi.org/10.1038/NCLIMATE2318.

Sitch, S., Smith, B., Prentice, I., Arneth, A., Bondeau, A., Cramer, W., Kaplan, J., Levis, S. Lucht, W., Sykes, M., Thonicke, K., Venevsky, S., 2003. Evaluation of ecosystem dynamics, plant geography and terrestrial carbon cycling in the LPJ dynamic global vegetation model. Global Change Biol. 9, 161-185.

Sitch, S., Huntingford, C. Gedney, N., Levy, P. E. Lomas, M. Piao, S.L Betts, R Ciais, P., Cox, P., Friedlingstein, P., Jones, C.D., Prentice, I.C., Woodward, F.I., 2008. Evaluation of the terrestrial carbon cycle, future plant geography and climatecarbon cycle feedbacks using five dynamic global vegetation models (DGVMs). Global Change Biol. 14, 2015-2039.

Sitch, S., Friedlingstein, P., Gruber, N., Jones, S., Murray-Tortarolo, G., Ahlström, A Doney, S., Graven, H., Heinze, C., Huntingford, C., Levis, S., Levy, P., Lomas, M., Poulter, B., Viovy, N., Zaehle, S., Zeng, N., Arneth, A., Bonan, G., Bopp, L., Canadell, J., Chevallier, F., Ciais, P., Ellis, R., Gloor, M., Peylin, P., Piao, S., Le Quéré, C., Smith, B., Zhu, Z., Myneni, R., 2013. Trends and drivers of regional sources and sinks of carbon dioxide over the past two decades. Biogeosci. Discuss. 10, 20113-20177.

Smith, N., Dukes, J., 2013. Plant respiration and photosynthesis in global-scale models: incorporating acclimation to temperature and $\mathrm{CO}_{2}$. Global Change Biol. 19, 45-63.

Smith, B., Prentice, I., Sykes, M., 2001. Representation of vegetation dynamics in the modelling of terrestrial ecosystems: comparing two contrasting approaches within European climate space. Global Ecol. Biogeogr. 10, 621-637.

Smith, B., Wårlind, D., Arneth, A., Hickler, T., Zaehle, S., 2014. Implications of incorporating $\mathrm{N}$ cycling and $\mathrm{N}$ limitations on primary production in an individual-based dynamic vegetation model. Biogeosci. Discuss. 11, 2017-2054.

Thonicke, K., Venevsky, S., Sitch, S., Cramer, W., 2001. The role of fire disturbance for global vegetation dynamics: coupling fire into a dynamic global vegetation model. Global Ecol. Biogeogr. 10, 661-677.

Todd-Brown, K.E.O., Randerson, J.T., Post, W.M. Hoffman, F.M. Tarnocai, C. Schuur, E.A.G., Allison, S.D., 2013. Causes of variation in soil carbon simulations from CMIP5 Earth system models and comparison with observations. Biogeosciences 10, 1717-1736, http://dx.doi.org/10.5194/bg-10-1717-2013.

UNFCCC, 2008. Reducing Emissions from Deforestation in Developing Countries: Approaches to Stimulate Action. Report on the Conference of the Parties on its Thirteenth Session, Held in Bali from 3 to 15 December 2007. Part Two: Action Taken by the Conference of the Parties at its Thirteenth Session United Nations, , pp. 8-10.

Wårlind, D., Smith, B., Hickler, T., Arneth, A., 2014. Nitrogen feedbacks increase future terrestrial ecosystem carbon uptake in an individual-based dynamic vegetation model. Biogeosci. Discuss. 11, 151-185.

Zaehle, S., Medlyn, B.E., De Kauwe, M.G., Walker, A.P., Dietze, M.C., Hickler, T., Luo, Y., Wang, Y.-P., El-Masri, B., Thornton, P., Jain, A., Wang, S., Wårlind, D., Weng, E., Parton, W., Iversen, C.M., Gallet-Budynek, A., McCarthy, H., Finzi, A., Hanson, P.J., Prentice, I.C., Oren, R., Norby, R.J., 2014. Evaluation of 11 terrestrial carbon-nitrogen cycle models against observations from two temperate free-air $\mathrm{CO}_{2}$ enrichment studies. New Phytol. 202, 803-822, http://dx.doi.org/10.1111/nph.12697. 


\section{Repository KITopen}

Dies ist ein Postprint/begutachtetes Manuskript.

Empfohlene Zitierung:

Bayer, A. D.; Pugh, T. A. M.; Krause, A.; Arneth, A.

Historical and future quantification of terrestrial carbon sequestration from a Greenhouse-

Gas-Value perspective.

2015. Global environmental change, 32 .

doi:10.5445/IR/110101557

Zitierung der Originalveröffentlichung:

Bayer, A. D.; Pugh, T. A. M.; Krause, A.; Arneth, A.

Historical and future quantification of terrestrial carbon sequestration from a Greenhouse-

Gas-Value perspective.

2015. Global environmental change, 32, 153-164.

doi:10.1016/i.gloenvcha.2015.03.004 